УДК 549.6

\title{
ОСОБЕННОСТИ СОСТАВА ПРИМЕСЕЙ В КРИСТАЛЛАХ БЕРИЛЛА РАЗЛИЧНОЙ ОКРАСКИ ЗАБАЙКАЛЬЯ
}

\author{
Юргенсон Георгий Александрович1, \\ yurgga@mail.ru
}

\section{Рихванов Леонид Петрович 2}

\author{
Борзенко Алёна Александровна', \\ avonanik@mail.ru \\ 1 Институт природных ресурсов, экологии и криологии Сибирского отделения Российской академии науки, \\ Россия, 672014, Чита, ул. Недорезова, 16а. \\ 2 Национальный исследовательский Томский политехнический университет, \\ Россия, 634050, г. Томск, пр. Ленина, 30.
}

\begin{abstract}
Актуальность работы заключается в изучении особенностей химического состава берилла, являющегося важным источником бериллия и ювелирным камнем, геммологические свойства которого определяются концентрациями и формами вхождения примесных химических элементов.

Целью исследования является определение содержаний примесных химических элементов в кристаллах берилла различной окраски, зависимостей между ними и связи с условиями образования.

Объекты: кристаллы берилла различной окраски грейзеновых (Шерловая Гора, Спокойнинское) и пегматитовых (Орловское, Саханайское) месторождений Восточного Забайкалья.

Методы: нейтронно-активационный и ICP MS.

Результаты. Установлен широкий диапазон концентраций элементов-примесей в 31 кристалле берилла различного ивета сидерофиллит-квариевых (Спокойнинское месторождеие вольфрама) и слюдисто-берилл-топаз-квариевых (Шерловая Гора) грейзенов, а также редкометалльных (Орловское) и камерных (Саханайское) пегматитов. Кристаллы берилла слюдистоберилл-топаз-кварцевых (Шерловая Гора) грейзенов отличаются низкими содержаниями натрия и цезия по сравнению с таковыми из сидерофиллит-квариевых грейзенов и пегматитов. Рубидий примерно в равной мере присутствует в кристаллах берилла всех изученных месторождений независимо от окраски. Впервые в них обнаружено золото, содержания которого имеют тенденцию к связи с кобальтом и цинком. Содержание мышьяка, изоморфнное вхождение которого в берилл маловероятно, также проявляет корреляцию к связи с цинком и кобальтом. Наиболее высокие содержания железа установлены в желтых, голубых и желто-зеленых кристаллах, входя как в тетраэдрические (голубые), так и в октаэдрические позиции (зеленые, желтье и желто-зеленые). Содержание урана и тория выше в кристаллах берилла грейзенов (Шерловая Гора, Спокойнинское) по сравнению с пегматитами. Содержания их имеют тенденцию к взаимозависимости при преобладании тория над ураном. Уран имеет связи с железом, наибольшие концентрации которого присущи зональным кристаллам с перерывами в росте. Торий находится в основном в цирконе, что подтверждается положительной корреляцией его содержаний с гафнием. Относительно широкий спектр примесей в кристаллах берилла обусловлен различиями в условиях образования (грейзены и пегматиты) и геохимическими особенностями минераообразующих фрлюидных систем, отображенных в составе фрлюидных включений.
\end{abstract}

\section{Ключевые слова:}

Берилл, элементы-примеси, взаимосвязи между содержаниями элементов-примесей, грейзены, пегматиты, Шерловая Гора, Орловское месторождение, Спокойнинское месторождение, Саханайское месторождение.

\section{Введение}

Поскольку берилл представляет собой один из главных носителей бериллия, индивиды которого характеризуются широкой цветовой гаммой, определяющей его ценность как ювелирного камня различной стоимости [1-5], изучение особенностей состава примесей и форм вхождения в структуру берилла, определяющих его окраску, представляется достаточно актуальным.

Известно [1-4, 6], что основной примесью, определяющей вариации окраски берилла, за исключением хрома и ванадия, ответственных за окраску изумруда, является железо. Именно соотношение количеств двух- и трехвалентного железа, как было нами показано в работе [7] с использованием ЭПР на примере аквамарина, зеленого берилла и гелиодора Шер- ловой Горы, определяет вариации и интенсивности голубой и зеленовато-голубой окраски аквамарина, обычного зеленого и желто-зеленого берилла и желтой окраски золотистого и желто-оранжевого гелиодора. Одной из нерешенных является проблема различий положения двухвалентного железа в аквамарине. В работе М.Н. Тарана и А.А. Вишневского [8] в какой-то мере подтверждено наше предположение о возможности нахождения его в тетраэдрической позиции в аквамарине и вызывающем его голубую окраску. Но Г. Спиноло с соавторами [9], на основе анализа оптических спектров поглощения, снятых при разных, в том числе и низких (16 К) температурах, и при сравнении их с эталонными спектрами водных растворов, содержащих $\mathrm{Fe}^{2+}$ и $\mathrm{Fe}^{3+}$, с помощью диаграмм d6 $\left(\mathrm{Fe}^{2+}\right)$ и d5 $\left(\mathrm{Fe}^{3+}\right)$ Танабе-Сугано получил 
удовлетворительную интерпретацию спектров для октаэдрической симметрии. Однако правомерность использования данных о спектрах водных растворов для выводов о положении двухвалентного железа в берилле вызывает сомнения и требует дальнейших доказательств. О двух формах вхождения железа в берилл могут свидетельствовать также установленные авторами два тренда зависимости содержаний железа и скандия [10]. Один из них характерен для желтых, зелено-голубых и оливково-зеленых (зеленые составляют лишь $17 \%$ ), а другой для зеленых $(60 \%)$ и голубых (35 \%). О.Н. Лопатиным было показано [11-13], что железо в результате имплантации может встраиваться в берилле как в тетраэдрические, так и в октаэдрические позиции [13]. Это же подтверждено методом Мёссбауэровской спетроскопии [13]. Содержание хрома и ванадия в берилле имеет принципиальное значение [1-5], так как определяет его принадлежность к изумруду. Примеси других сидерофильных элементов, в частности кобальта, никеля, золота, а также халькофильных, элементов V группы (мышьяк, сурьма и висмут) в берилле не изучались, а по примесям РЗЭ имеются лишь отрывочные данные.

Предлагаемая работа посвящена изучению возможных корреляций между содержаниями широкого круга химических элементов, в том числе и железа, в кристаллах берилла различной окраски.

\section{Материал и методы исследования}

Для изучения примесей выбраны кристаллы берилла висмут-вольфрам-олово-бериллиевого с камнесамоцветным сырьем месторождения Шерловая Гора грейзеновой формации, входящего в состав крупной Шерловогорской рудно-магматической системы, связанной с Шерловогрским гранитным массивом кукульбейского интрузивного комплекса, радиологический возраст которого, определенный калийаргоновым методом, составляет 154-147 млн лет [14] Он представляет собой восточный фрагмент АдунЧелон-Шерловогорского интрузивного тела. Калийаргоновый возраст по сидерофиллиту топазсидерофиллитовых грейзенов, в кварцево-жильных телах которых находится берилл, по Д.О. Онтоеву [15] равен $154 \pm 6$ млн лет. Поскольку кварцево-жильные тела, содержащие берилл, в большинстве случаев имеют постепенные контакты с продуктивными грейзенами и постепенные переходы между ними, можно полагать, что берилл формировался в этом же возрастном диапазоне.

Первые данные о составе топаза и берилла Шерловой Горы опубликовали В.Ф. Барабанов и Л.О. Ступкина [16], затем в 1963 г. G. Tzschorn [17], сотрудничавший с В.Ф. Барабановым. Более полные результаты изучения содержаний $\mathrm{Fe}, \mathrm{Al}, \mathrm{Cs}, \mathrm{K}, \mathrm{Na}$, его первые ИКспектры, особенности зональности кристаллов берилла Шерловой Горы опубликованы В.Ф. Барабановым в 1975 г. [18]. Однако полных количественных анализов, соответствующих современным методам исследований, получено не было. Более того, изучение касалось преимущественно участка Поднебесных и Ка- рамышевского отрога. Поскольку месторождение Шерловая Гора представлено в основном жильными телами висмут-вольфрам-олово-берилл-топаз-кварцевого состава в слюдисто-кварцево-топазовых грейзенах и миароловыми гранитами, для сравнения привлечены данные химического состава желтовато-зеленых кристаллов Спокойнинского вольфрамового грейзеновой формации, Орловского тантал-литиевого и желтые Саханайского бериллиевого месторождений, связанных с пегматитами. Берилл Орловского месторождения происходит из редкометалльных (литий-ниобийтанталовых) колумбит-микролит-лепидолит (циннвальдит)-кварц-альбит-амазонитовых пегматитов, Саханайского - из камерного берилл-мусковитальбит-микроклин-кварцевого пегматита. Кристаллы Спокойнинского вольфрамового месторождения находятся в слюдяных грейзенах, где слюда представлена в основном зеленоватым сидерофиллитом. Берилл ассоциирует со слюдой, дымчатым кварцем и вольфрамитом. Все пегматиты и грейзены являются продуктами эволюции литий-фтористых гранитных магм кукульбейского интрузивного комплекса, с которым связаны все редкометалльные месторождения Монголо-Охотского минерагенического пояса [19]. Месторождения расположены на Юго-Востоке Забайкальского края (рис. 1).

Месторождение Шерловая Гора открыто в 1723 г. и до сих пор продолжает оставаться почти единственным в России источником благородных разновидностей берилла ювелирного качества, неповторимых по разнообразию и насыщенности цвета. Геммологическая характеристика ювелирного берилла и геологическое строение месторождения даны в [20, 21] и здесь не рассматривается. В 1787 г. месторождение стало собственностью императрицы Екатерины II, которая организовала систематическую многолетнюю добычу. По современным оценкам за почти 300 летний период добыто более 5 т кондиционного кристаллосырья.

Кристаллы берилла месторождения Шерловая Гора происходят из различных участков добычи, исторически определившихся за время его разработки (рис. 2).

Изученные кристаллы представлены в основном относительно бледно-окрашенными, но совершенными разностями. Размеры их варьируют от 15 до 42 мм по оси $c$ и от 3 до 6 мм по оси $a$, а их фрагменты, использованные для приготовления проб - от 7 до 10 мм по оси $c$ и от 2 до 5 мм по оси $a$. Такая размерность типична для кристаллов, лишенных видимых дефектов и механических примесей. Это важно для выявления возможных связей окраски и примесей. Среди изученных кристаллов берилла бледноголубых - 10, бледно-зеленых - 8, желто-зеленых - 6, желтых - 4 и бесцветных - 3. Число использованных кристаллов 31, приготовленных из них проб 39. Во избежание заражения проб берилла при истирании использовалась ступка, изготовленная из жильного кварца, лишенного примесей, а пест - из кристалла горного хрусталя. 


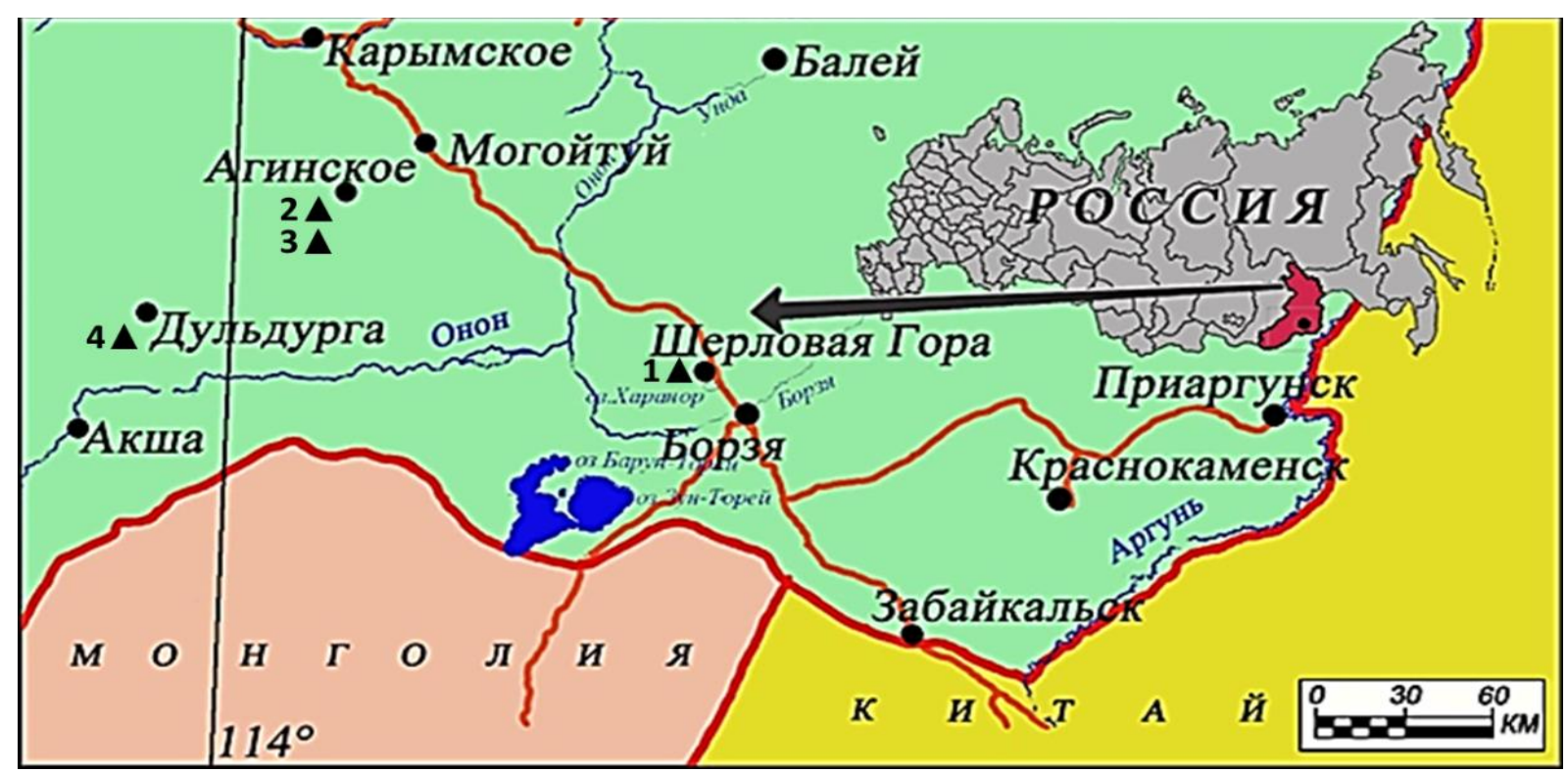

Рис. 1. Локация месторождений изученных кристаллов берилла: 1- Шерловая Гора; 2 - Орловское; 3 - Спокойнинское; 4 - Саханайское

Fig. 1. Location of deposits of studied beryl crystals: 1 -Sherlovaya Gora; 2 -Orlovskoe; 3 - Spokoininskoe; 4 -Sakhanayskoe

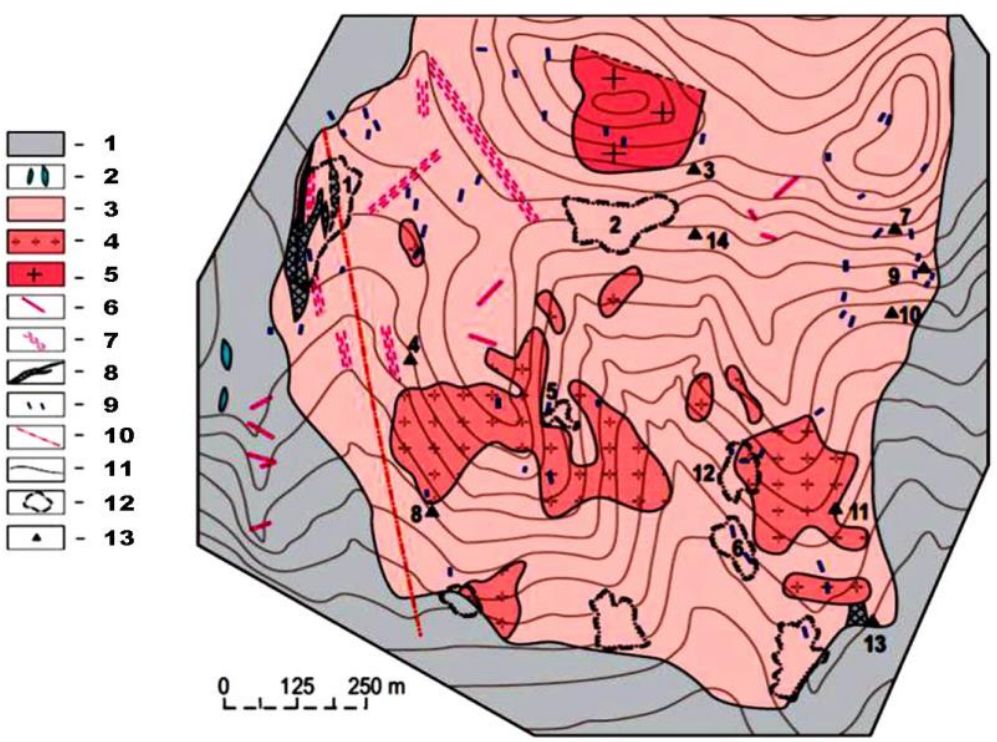

Puc. 2. Геологическая карта месторождения Шерловая Гора с указанием основных мест добычи самоцветов по [21]: 1 - роговики; 2 - габбро, диориты; 3 - граниты порфировидные; 4 - граниты крупнозернистые; 5 - гранитпорфиры; 6 - аплиты; 7 - зоны трещиноватости; 8 - грейзеновые тела; 9 - внемасштабные зоны грейзенизаиии; 10 - зоны дробления; 11 - геологические граничы; 12 - старые выработки и отвалы и их номера на карте; 13 - внемсаштабные выработки и их номера. Горные выработки на карте: 1 - Поднебесных, 2 - Новиковская, 3 - Белотопазовая, 4-Мелехинская-1, 5 - Мелехинская-2, 6-Гелиодоровая, 7 - Лизкина Яма, 8 - Мелехинская, 9 - Кондратьевская, 10 - Золотой Мыс, 11 - Лукаво-Золотая, 12 - Миллионная, 13 - Золотой Отрог

Fig. 2. Geological map of Sherlovogorsk aquamarine field indicating the main places of gem mining according to [21]: 1 hornfels; 2 -gabbros, diorites; 3 - porphyraceous granites; 4 - coarse granites; 5 - granite-porphyry; 6 -aplites; 7 - fracture zones; 8 - greisen bodies; 9 - off-scale greisenization zones; 10 - crushing zones; 11 - geological boundaries; 12 - old workings and dumps and their numbers on the map; 13 -out-of-scale workings and their numbers. Mine workings on the map: 1 - Podnebesnykh, 2 - Novikovskaya, 3 - Belotopazovaya, 4-Melekhinskaya-1, 5-Melekhinskaya-2, 6 - Geliodorovaya, 7 - Lizkina Yama, 8 - Melekhinskaya, 9 - Kondratievskaya, 10 - Zolotoy Mys, 11 - Lukavo-Zolotaya, 12 - Millionnaya, 13 -Zolotoy otrog

Химический состав определен методом нейтронноактивационного анализа (ИНАА), являющимся современным высокочувствительным видом анализа на исследовательском реакторе ИРТ-Т в ядерногеохимической лаборатории (ЯГЛ) ТПУ (аттестат ак- кредитации № POCC RU.0001.518623 от 10.10.2011 г., аналитики - с.н.с. Судыко А.Ф., Богутская Л.Ф.). Плотность потока тепловых нейтронов в канале облучения составляла $2 \cdot 1013$ нейтр./(cм².c). Продолжительность облучения проб 20 часов. Измерение произ- 
водилось на многоканальном анализаторе импульсов AMA 02Ф с полупроводниковым Ge-Li детектором. Этим методом определены содержания $\mathrm{Na}, \mathrm{Ca}, \mathrm{Sc}, \mathrm{Cr}$, $\mathrm{Fe}, \mathrm{Co}, \mathrm{Zn}, \mathrm{As}, \mathrm{Br}, \mathrm{Rb}, \mathrm{Sr}, \mathrm{Ag}, \mathrm{Sb}, \mathrm{Cs}, \mathrm{Ba}, \mathrm{La}, \mathrm{Ce}, \mathrm{Sm}, \mathrm{Eu}$, $\mathrm{Tb}, \mathrm{Yb}, \mathrm{Lu}, \mathrm{Hf}, \mathrm{Ta}, \mathrm{Au}, \mathrm{Th}, \mathrm{U}$ согласно инструкции НСАМ ВИМС № 410-ЯФ. Внутренний контроль показал удовлетворительную сходимость результатов. Кроме того, эти же элементы, кроме брома и золота, определены методом ICP MS в лаборатории SGS Boсток-лимитед, что показало удовлетворительную сходимость результатов. Руководитель А. Шацкий. Всего выполнен анализ 31 кристалла и 8 их фрагментов.

\section{Результаты и их обсуждение}

Результаты анализов кристаллов берилла представлены в табл. 1. Из неё видно, что концентрации химических элементов достаточно вариабельны.

Для определенных групп химических элементов, которые могут входить в структуру берилла изоморфно или как неструктурные примеси, выполнено изучение их возможных взаимосвязей. Известно [1-4, $6,22-26]$, что изоморфными примесями в берилл могут быть Fe, Cr, V, Sc, Mn, Na, Cs, Li и некоторые другие.

Таблица 1. Содержания элементов-примесей в кристаллах берилла

Table 1. Content of impurity elements in beryl crystals

\begin{tabular}{|c|c|c|c|c|c|c|c|c|}
\hline \multirow{2}{*}{$\begin{array}{l}\text { Образец } \\
\text { Sample }\end{array}$} & \multicolumn{3}{|c|}{$\begin{array}{l}\text { Элемент и его содержание, мас. \% } \\
\text { Element and its content, wt. \% }\end{array}$} & \multicolumn{4}{|c|}{$\begin{array}{l}\text { Элемент и его содержание, ppm } \\
\text { Element and its content, ppm }\end{array}$} & \multirow{2}{*}{$\begin{array}{c}\text { Месторождение } \\
\text { Deposit }\end{array}$} \\
\hline & $\mathrm{Fe}$ & $\mathrm{Na}$ & Cs & $\mathrm{U}$ & Th & $\mathrm{Au}$ & $\mathrm{Co}$ & \\
\hline OP-1 & 0,648 & 0,456 & 0,081 & 0,060 & $<0,10$ & 0,099 & 0,91 & \multirow{6}{*}{$\begin{array}{l}\text { Орловское } \\
\text { Orlovskoe }\end{array}$} \\
\hline OP-5 & 0,332 & 0,276 & 0,058 & 0,711 & 0,08 & 0,090 & 0,48 & \\
\hline OP-7 & 0,378 & 0,295 & 0,053 & 1,183 & 0,47 & 0,057 & 0,13 & \\
\hline OP-1-1 & 0,510 & 0,371 & 0,075 & 0,120 & 0,20 & - & 0,70 & \\
\hline OP-5-1 & 0,310 & 0,237 & 0,054 & 0,260 & 0,20 & - & $<0,50$ & \\
\hline OP-7-1 & 0,290 & 0,245 & 0,047 & 0,160 & 0,10 & - & $<0,50$ & \\
\hline СП-18 & 0,284 & 0,488 & 0,131 & 4,355 & 0,13 & $<0,005$ & $<0,20$ & \multirow{2}{*}{$\begin{array}{c}\text { Спокойнинское } \\
\text { Spokoyninskoe }\end{array}$} \\
\hline СП-18-1 & 0,240 & 0,423 & 0,117 & 2,640 & $<0,10$ & - & $<0,50$ & \\
\hline CX-18-01 & 0,526 & 0,266 & 0,038 & 1,597 & 1,43 & $<0,005$ & 0,43 & \multirow{2}{*}{$\begin{array}{l}\text { Саханайское } \\
\text { Sakhanayskoe }\end{array}$} \\
\hline CX-18-01-1 & 0,450 & 0,237 & 0,037 & 0,300 & 1,00 & - & 0,60 & \\
\hline ШГ-10/174 & 0,628 & 0,058 & 0,076 & 2,168 & 1,31 & 0,030 & 0,93 & \multirow{29}{*}{$\begin{array}{l}\text { Шерловая Гора } \\
\text { Sherlovaya Gora }\end{array}$} \\
\hline ШГ-12/151 & 0,420 & 0,050 & 0,031 & 0,564 & $<0,10$ & 0,027 & 0,26 & \\
\hline ШГ-12/153 & 0,388 & 0,039 & 0,017 & 0,306 & 1,23 & 0,005 & 0,10 & \\
\hline ШГ-12/151-1 & 0,340 & 0,047 & 0,033 & 0,050 & 0,30 & - & $<0,50$ & \\
\hline ШГ-12/153-1 & 0,330 & 0,054 & 0,019 & 0,090 & 0,20 & - & $<0,50$ & \\
\hline ШГ-12/213 & 0,810 & $<0,100$ & 0,055 & 5,059 & 20,04 & 0,017 & $<0,20$ & \\
\hline ШГ-12/213-1 & 0,720 & 0,052 & 0,056 & 4,930 & 12,70 & - & $<0,50$ & \\
\hline ШГ-12имп & 0,433 & 0,075 & 0,016 & 1,842 & 0,19 & 0,031 & 0,28 & \\
\hline ШГ-14имп & 0,340 & 0,041 & 0,022 & 0,873 & $<0,10$ & 0,002 & $<0,20$ & \\
\hline ШГ-15имп & 0,394 & 0,042 & 0,023 & 0,989 & $<0,10$ & 0,010 & 0,52 & \\
\hline ШГ-16/20 & 0,735 & 0,155 & 0,044 & 0,777 & 0,52 & 0,012 & $<0,20$ & \\
\hline ШГ-16/20-1 & 0,650 & 0,142 & 0,044 & 0,140 & 0,20 & - & 0,60 & \\
\hline ШГ-17/100-2 & 0,650 & 0,056 & 0,067 & 0,759 & $<0,10$ & 0,007 & 0,52 & \\
\hline ШГ-17/104 & 0,096 & 0,046 & 0,061 & 1,320 & $<0,10$ & 0,115 & $<0,20$ & \\
\hline ШГ-17/104-1 & 0,53 & 0,052 & 0,061 & 0,070 & $<0,10$ & - & $<0,50$ & \\
\hline ШГ-17имп & 0,096 & 0,061 & 0,106 & 0,931 & 0,01 & 0,021 & $<0,20$ & \\
\hline ШГ-18/20 & 0,331 & 0,187 & 0,210 & 1,443 & 0,09 & 0,008 & 0,27 & \\
\hline ШГ-18/20-1 & 0,500 & 0,148 & 0,027 & 0,600 & 0,10 & - & $<0,50$ & \\
\hline ШГ-18/23 & 0,697 & 0,061 & 0,036 & 1,555 & 0,05 & $<0,005$ & $<0,20$ & \\
\hline ШГ-18-21 & 0,506 & 0,058 & 0,041 & 1,491 & $<0,10$ & 0,007 & 0,29 & \\
\hline ШГ-18-21-1 & 0,480 & 0,052 & 0,043 & 0,240 & $<0,10$ & - & $<0,50$ & \\
\hline ШГ-18имп & 0,619 & 0,054 & 0,056 & 0,474 & 0,29 & 0,085 & 0,07 & \\
\hline ШГ-21имп & 0,566 & 0,085 & 0,075 & 3,753 & 1,61 & 0,044 & 0,49 & \\
\hline ШГ-23имп & 0,767 & 0,058 & 0,031 & 2,981 & 14,67 & 0,057 & 0,17 & \\
\hline ШГ-24имп & 0,536 & 0,061 & 0,056 & 0,284 & $<0,10$ & 0,425 & 0,23 & \\
\hline ШГ-27имп & 0,633 & 0,063 & 0,039 & 10,02 & 1,13 & 0,043 & $<0,20$ & \\
\hline ШГ-28имп & 0,710 & 0,038 & 0,038 & 1,162 & $<0,10$ & 0,012 & 0,27 & \\
\hline ШГ-4имп & 0,460 & 0,081 & 0,022 & 1,214 & $<0,10$ & 0,037 & $<0,20$ & \\
\hline ШГ-7имп & 0,411 & 0,139 & 0,061 & 1,813 & 0,25 & 0,020 & 0,50 & \\
\hline Образец & \multicolumn{7}{|c|}{ Элемент и его содержание/Element and its content, ppm } & \multirow{2}{*}{$\begin{array}{c}\text { Месторождение } \\
\text { Deposit }\end{array}$} \\
\hline Sample & $\mathrm{Rb}$ & As & $\mathrm{Zn}$ & $\mathrm{Cr}$ & Hf & $\mathrm{Sb}$ & Sc & \\
\hline OP-1 & 142,85 & 5,628 & 172,3 & $<0,50$ & 0,44 & $<0,1$ & 26,2 & \multirow{6}{*}{$\begin{array}{l}\text { Орловское } \\
\text { Orlovskoe }\end{array}$} \\
\hline OP-5 & 77,70 & 0,006 & 211,5 & $<0,50$ & 0,06 & 0,01 & 8,01 & \\
\hline OP-7 & 100,09 & $<0,500$ & 155,7 & 1,57 & 0,15 & 0,13 & 16,9 & \\
\hline OP-1-1 & 117,00 & 0,0005 & 127,0 & 0,001 & - & $<0,5$ & 20,0 & \\
\hline OP-5-1 & 78,00 & 0,0005 & 166,0 & $<0,001$ & - & $<0,5$ & 10,0 & \\
\hline OP-7-1 & 78,30 & 0,0005 & 117,0 & $<0,001$ & - & $<0,5$ & 20,0 & \\
\hline СП-18 & 18,54 & 21,586 & 105,4 & $<0,50$ & $<0,02$ & 0,036 & 0,8 & \multirow{2}{*}{$\begin{array}{c}\text { Спокойнинское } \\
\text { Spokoyninskoe }\end{array}$} \\
\hline СП-18-1 & 19,60 & 0,002 & 74,0 & $<0,001$ & - & $<0,5$ & 10,0 & \\
\hline CX-18-01 & 34,27 & 0,375 & 181,3 & 1,17 & 0,15 & 0,12 & 2,3 & \multirow{2}{*}{$\begin{array}{l}\text { Саханайское } \\
\text { Sakhanayskoe }\end{array}$} \\
\hline CX-18-01-1 & 28,60 & 0,0005 & 145,0 & $<0,001$ & - & $<0,5$ & 10,0 & \\
\hline
\end{tabular}


Известия Томского политехнического университета. Инжиниринг георесурсов. 2021. Т. 332. № 4. 159-172

Юргенсон Г.А., Рихванов Л.П., Борзенко А.А. Особенности состава примесей в кристаллах берилла различной окраски Забайкалья

\begin{tabular}{|c|c|c|c|c|c|c|c|c|c|}
\hline ШГ-10/174 & 72,37 & 4,419 & \multicolumn{2}{|c|}{$<2,0$} & $<0,50$ & 1,54 & 1,27 & 136,8 & \\
\hline ШГ-12/151 & $<1,00$ & $<0,500$ & \multicolumn{2}{|c|}{124,9} & $<0,50$ & 0,05 & 0,42 & 22,0 & \\
\hline ШГ-12/153 & 7,27 & 2,092 & \multicolumn{2}{|c|}{107,3} & 1,21 & 0,42 & 0,18 & 13,0 & \\
\hline ШГ-12/151-1 & 5,60 & 0,0005 & \multicolumn{2}{|c|}{55,0} & 0,002 & - & $<0,5$ & 150,0 & \\
\hline ШГ-12/153-1 & 5,30 & 0,0005 & \multicolumn{2}{|c|}{81,0} & $<0,001$ & - & $<0,5$ & 140,0 & \\
\hline ШГ-12/213 & 37,54 & 31,21 & \multicolumn{2}{|c|}{188,9} & 6,32 & 6,80 & 1,10 & 87,7 & \\
\hline ШГ-12/213-1 & 32,60 & 0,004 & \multicolumn{2}{|c|}{86,0} & 0,001 & - & 2,2 & 70,0 & \\
\hline ШГ-12имп & 1,49 & 0,906 & \multicolumn{2}{|c|}{196,7} & $<0,50$ & 0,06 & 0,23 & 4,4 & \\
\hline ШГ-14имп & 0,12 & $<0,5$ & \multicolumn{2}{|c|}{90,6} & $<0,50$ & 0,08 & 0,14 & 9,7 & \\
\hline ШГ-15имп & $<1,00$ & 0,788 & 92,3 & & $<0,50$ & 0,19 & $<0,1$ & 15,5 & \\
\hline ШГ-16/20 & $<1,00$ & 4,159 & 120 & & 3,17 & 0,22 & 0,34 & 46,5 & \\
\hline ШГ-16/20-1 & 17,60 & 0,0005 & 60,0 & & 0,001 & - & $<0,5$ & 40,0 & \\
\hline ШГ-17/100-2 & $<1,00$ & $<0,500$ & 116, & & $<0,50$ & 3,05 & $<0,1$ & 52,6 & \\
\hline ШГ-17/104 & 6,55 & $<0,500$ & 75,2 & & $<0,50$ & 0,20 & $<0,1$ & 51,1 & \\
\hline ШГ-17/104-1 & 12,40 & 0,0005 & 45,0 & & $<0,001$ & - & $<0,5$ & 40,0 & Шерловая Гора \\
\hline ШГ-17имп & 5,77 & $<0,5$ & 125, & & $<0,50$ & 0,08 & 0,02 & 5,4 & \\
\hline ШГ-18/20 & $<1,00$ & 19,876 & 169, & & $<0,50$ & 0,19 & 0,17 & 13,7 & \\
\hline ШГ-18/20-1 & 5,60 & 0,002 & 161, & & 0,001 & - & $<0,5$ & 20,0 & \\
\hline ШГ-18/23 & 7,50 & 3,550 & 100, & & 0,59 & 0,081 & $<0,1$ & 29,8 & \\
\hline ШГ-18-21 & $<1,00$ & 11,926 & 116, & & 8,84 & 0,49 & $<0,1$ & 37,2 & \\
\hline ШГ-18-21-1 & 14,80 & 0,001 & 43,0 & & 0,002 & - & $<0,5$ & 30,0 & \\
\hline ШГ-18имп & 3,64 & 2,080 & 155, & & $<0,50$ & 0,98 & 0,20 & 77,2 & \\
\hline ШГ-21имп & 2,25 & 9,522 & 128, & & 7,37 & 10,07 & 0,41 & 75,6 & \\
\hline ШГ-23имп & 13,17 & 1,968 & 126, & & $<0,50$ & 0,03 & 0,11 & 18,7 & \\
\hline ШГ-24имп & 1,55 & 4,442 & 128, & & $<0,50$ & 0,04 & 0 & 89,3 & \\
\hline ШГ-27имп & 6,80 & 44,003 & 129, & & $<0,50$ & 41,67 & 0,93 & 66,5 & \\
\hline ШГ-28имп & $<1,00$ & 3,103 & 105 , & & $<0,50$ & $<0,02$ & 0,13 & 47,0 & \\
\hline ШГ-4имп & 5,54 & 0,571 & 194,8 & & $<0,50$ & 0,09 & $<0,1$ & 3,4 & \\
\hline ШГ-7имп & 37,58 & $<0,500$ & 204, & & $<0,50$ & 0,55 & 0,29 & 108,5 & \\
\hline Образец & & Элемент & содерж & ue/Elen & ent and $\mathrm{i}$ & ontent, & & & Месторождение \\
\hline Sample & $\mathrm{La}$ & $\mathrm{Ce}$ & $\mathrm{Nd}$ & $\mathrm{Sm}$ & $\mathrm{Eu}$ & $\mathrm{Tb}$ & $\mathrm{Yb}$ & $\mathrm{Lu}$ & Deposit \\
\hline OP-1 & 0,969 & 2,010 & $<0,2$ & 0,442 & 0,180 & $<0,1$ & 0,910 & 0,113 & \\
\hline OP-5 & 0,170 & $<1$ & $<0,2$ & 0,089 & 0,285 & 0,090 & 0,182 & 0,042 & \\
\hline OP-7 & 0,282 & 1,120 & $<0,2$ & 0,267 & 0,318 & 0,064 & 0,489 & 0,067 & Орловское \\
\hline OP-1-1 & 0,8 & 1,5 & 1,1 & 0,4 & 0,06 & 0,10 & 0,5 & 0,09 & Orlovskoe \\
\hline OP-5-1 & $<0,1$ & $<0,1$ & $<0,1$ & $<0,1$ & $<0,05$ & $<0,05$ & 0,1 & $<0,05$ & \\
\hline OP-7-1 & 0,1 & 0,3 & 0,3 & 0,3 & $<0,05$ & 0,11 & 0,5 & 0,06 & \\
\hline СП-18 & 0,237 & 0,432 & 24,07 & $<0,2$ & 0,481 & $<0,1$ & $<0,01$ & $<0,05$ & Спокойнинское \\
\hline СП-18-1 & $<0,1$ & $<0,1$ & $<0,1$ & $<0,1$ & $<0,05$ & $<0,05$ & $<0,1$ & $<0,05$ & Spokoyninskoe \\
\hline CX-18-01 & 1,176 & 2,812 & $<0,2$ & 0,373 & 0,477 & 0,067 & 0,338 & 0,136 & Саханайское \\
\hline CX-18-01-1 & 0,9 & 1,8 & 1,2 & 0,4 & 0,06 & 0,08 & 0,5 & 0,07 & Sakhanayskoe \\
\hline ШГ-10/174 & 0,939 & 3,454 & $<0,2$ & 0,174 & 0,087 & $<0,1$ & $<0,01$ & 0,470 & \\
\hline ШГ-12/151 & 0,003 & $<1$ & 1,792 & 0,056 & 0,176 & $<0,1$ & 0,032 & 0,017 & \\
\hline ШГ-12/153 & 1,033 & 2,776 & 0,254 & 0,258 & 0,229 & $<0,1$ & $<0,01$ & 0,052 & \\
\hline ШГ-12/151-1 & $<0,5$ & 0,2 & $<0,1$ & $<0,1$ & $<0,05$ & $<0,05$ & $<0,1$ & $<0,05$ & \\
\hline ШГ-12/153-1 & $<0,5$ & 0,3 & $<0,1$ & $<0,1$ & $<0,05$ & $<0,05$ & $<0,1$ & $<0,05$ & \\
\hline ШГ-12/213 & 11,347 & 27,16 & 15,30 & 2,650 & 0,584 & 0,104 & 0,930 & 0,219 & \\
\hline ШГ-12/213-1 & 9,4 & 18,5 & 9,4 & 2,5 & 0,05 & 0,32 & 1,1 & 0,17 & \\
\hline ШГ-12имп & 0,162 & 1,024 & $<0,2$ & $<0,2$ & 0,258 & $<0,1$ & 0,047 & 0,014 & \\
\hline ШГ-14имп & 0,105 & 0,972 & $<0,2$ & 0,044 & 0,268 & $<0,1$ & 0,040 & 0,013 & \\
\hline ШГ-15имп & 0,045 & $<1$ & $<0,2$ & 0,011 & 0,246 & $<0,1$ & 0,004 & $<0,05$ & \\
\hline ШГ-16/20 & 0,774 & $<1$ & 0,397 & 0,050 & 0,121 & 0,658 & 0,359 & 0,191 & \\
\hline ШГ-16/20-1 & 0,8 & 1,3 & 1,2 & 0,4 & 0,05 & 0,08 & 0,4 & 0,10 & \\
\hline ШГ-17/100-2 & 0,087 & 2,615 & 1,043 & 0,173 & 0,190 & 0,073 & 0,142 & 0,168 & \\
\hline ШГ-17/104 & 0,223 & 1,657 & $<0,2$ & $<0,2$ & $<0,1$ & 0,237 & $<0,01$ & 0,050 & \\
\hline ШГ-17/104-1 & $<0,1$ & $<0,1$ & $<0,1$ & $<0,1$ & $<0,05$ & $<0,05$ & $<0,1$ & $<0,05$ & Шерловая 1 ора \\
\hline ШГ-17имп & 0,106 & 0,221 & $<0,2$ & $<0,2$ & 0,318 & 0,017 & 0,001 & 0,002 & Sherlovaya Gora \\
\hline ШГ-18/20 & 0,210 & 1,180 & $<0,2$ & 0,188 & 0,203 & 0,113 & 1,010 & 0,087 & \\
\hline ШГ-18/20-1 & 0,1 & $<0,1$ & 0,3 & 0,3 & $<0,05$ & 0,15 & 0,7 & 0,12 & \\
\hline ШГ-18/23 & 0,244 & 0,155 & $<0,2$ & 0,044 & 0,129 & $<0,1$ & $<0,01$ & 0,019 & \\
\hline ШГ-18-21 & 0,495 & 0,576 & 1,580 & 0,031 & 0,206 & $<0,1$ & 0,066 & $<0,05$ & \\
\hline ШГ-18-21-1 & $<0,1$ & $<0,1$ & 0,1 & $<0,1$ & $<0,05$ & $<0,05$ & 0,2 & $<0,05$ & \\
\hline ШГ-18имп & $<0,1$ & $<1$ & $<0,2$ & 0,107 & 0,084 & 0,605 & 0,704 & 0,287 & \\
\hline ШГ-21имп & $<0,1$ & 0,839 & $<0,2$ & 0,076 & 0,083 & 0,256 & 0,623 & 0,211 & \\
\hline ШГ-23имп & 10,781 & 22,954 & 8,807 & 3,901 & 0,506 & $<0,1$ & 0,368 & 0,043 & \\
\hline ШГ-24имп & 0,364 & $<1$ & 3,532 & 0,075 & 0,070 & $<0,1$ & 0,045 & 0,037 & \\
\hline ШГ-27имп & 1,124 & 3,064 & $<0,2$ & $<0,2$ & $<0,1$ & $<0,1$ & 2,101 & 0,330 & \\
\hline ШГ-28имп & 0,052 & 0,504 & $<0,2$ & $<0,2$ & 0,276 & $<0,1$ & $<0,01$ & 0,114 & \\
\hline ШГ-4имп & 0,142 & 0,289 & 1,866 & 0,020 & 0,343 & 0,002 & 0,014 & $<0,05$ & \\
\hline ШГ-7имп & 0,471 & $<1$ & $<0,2$ & 0,219 & $<0,1$ & $<0,1$ & 0,264 & 0,219 & \\
\hline
\end{tabular}


На рис. 3, 4 представлено распределение щелочных элементов в кристаллах различной окраски. Они, по данным [1, 22-26], входят в состав берилла в каче- стве компенсаторов зарядов и наряду с ОН-группой располагаются в каналах, образуемых кольцами кремнекислородных тетраэдров.

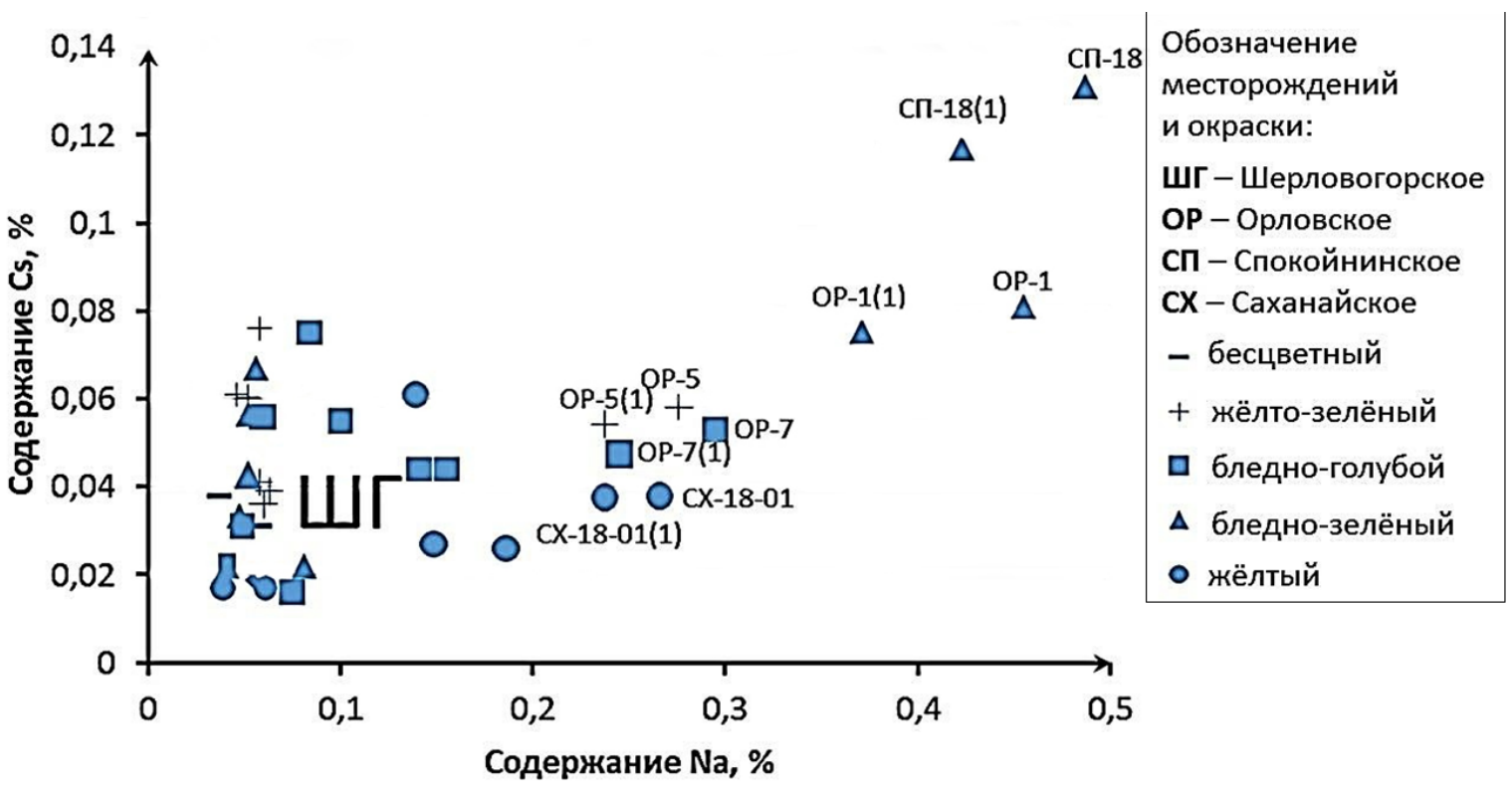

Pис. 3. Тренд зависимости содержаний натрия и цеезия в кристаллах берилла

Fig. 3. Trend of dependence of sodium and cesium contents in beryl crystals

По уменьшению средних содержаний натрия и цезия в кристаллах берилла месторождения выстраиваются в ряд: Спокойнинское (средние содержания соответственно (ppm) - 4880 и 1313,4), Орловское (3430 и 638,7$)$, Саханайское $(2660$ и 380,5$)$, Шерловая Гора (720 и 413,8). Максимальное среднее содержание рубидия обнаружено в берилле Орловского, а минимальное - Шерловой Горы.

Рассмотрение соотношений щелочных элементов, выполняющих роль компенсаторов дефицита зарядов, показало, что между содержаниями цезия и натрия для всего массива проб намечается прямая связь (рис. 3). Но для кристаллов Шерловой Горы она не прослеживается, и весь массив данных имеет форму треугольника, обозначенного на рис. 3 буквами ШГ, ограничивающего содержания натрия в пределах 0,04-0,19\% и цезия 0,008-0,078 \%. При этом содержания этих элементов, особенно натрия в кристаллах берилла Шерловой Горы, существенно меньше, чем таковых из других месторождений. Причину этого еще предстоит выяснить. Минимальны содержания натрия и цезия в бесцветных кристаллах и максимальны в бледно-салатно-зеленых Спокойнинского и Орловского месторождений. В целом содержания этих элементов возрастают в ряду слюдистокварцево-берилловые грейзены и миароловые граниты $\rightarrow$ пегматиты $\rightarrow$ сидерофиллит-кварцевые грейзены.

Относительно рубидия (рис. 4) эта тенденция сохраняется, но его содержания характеризуются весьма широкими пределами для кристаллов Шерловой Горы (10-90 ppm) при относительно небольшом содержании натрия (400-1400 ppm) (табл. 1). Содержания рубидия в кристаллах берилла из сидерофиллиткварцевых грейзенов Спокойнинского месторожде- ния вольфрама не превышают средних содержаний его в берилле грейзенов и миароловых полостей Шерловой Горы, отличаясь существенно высоким содержанием натрия. Содержание рубидия в берилле из пегматитов Саханайского и Орловского месторождений существенно выше таковых для грейзенов и находятся в пределах 60-110 ppm. При этом в желтом берилле Саханайского месторождения камерных пегматитов содержания его ниже таковых в кристаллах берилла редкометалльных пегматитов Орловского месторождения и почти не зависят от их окраски. Берилл Орловского месторождения отличается максимальными содержаниями рубидия и высокими натрия (табл. 1).

Весьма показательны соотношения содержаний рубидия и цезия (рис. 4).

Прослеживается генеральная положительная связь между их содержаниями, особенно четко проявленная в ряду кристаллов из пегматитов, которая подчеркивает возрастание содержания обоих элементов в редкометалльных (Орловское) пегматитах по сравнению с камерными (Саханайское). При этом в кристаллах из пегматитов они минимальны в их желтых разностях, несколько возрастая в желто-зеленых и бледноголубых, достигая максимума в бледно-зеленых. В кристаллах из полостей в жильных телах в слюдистоберилл-топаз-кварцевых грейзенов Шерловой Горы эта тенденция не проявлена.

Кристаллы берилла из сидерофиллит-кварцевых грейзенов Спокойнинского месторождения отличаются максимальными содержаниями цезия при минимальном содержании рубидия и тенденцией к обратной зависимости между ними в ряду: сидерофиллит-кварцевые грейзены (Спокойнинское) $\rightarrow$ редкометалльные (Орловское) пегматиты. Кристаллы бе- 
рилла Шерловой Горы содержат, таким образом, минимум щелочных металлов. Полученные различия тенденций во взаимосвязях между цезием и рубидием в пегматитах и грейзенах определяются тем, что натрий преимущественно изоморфно замещается цезием, а калий - рубидием.

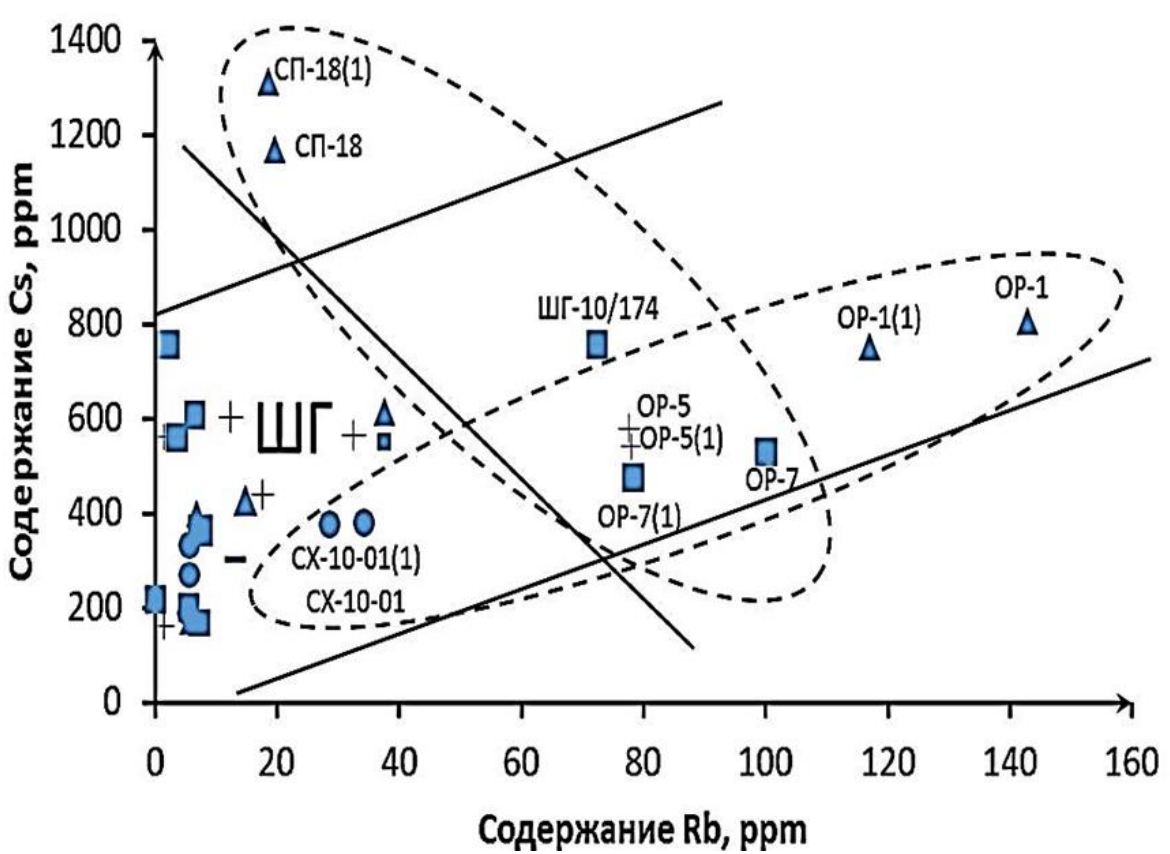

\begin{tabular}{|l|}
\hline Обозначение \\
месторождений \\
и окраски: \\
шг-Шерловогорское \\
ор-Орловское \\
СП-Спокойнинское \\
сX-Саханайское \\
- бесцветный \\
+ жёлто-зелёный \\
口 бледно-голубой \\
А бледно-зелёный \\
- жёлтый
\end{tabular}

Pис. 4. Зависимость содержаний цезия и рубидия в кристаллах берилла

Fig. 4. Dependence of cesium and rubidium contents in beryl crystals

Из типичных изоморфных примесей в берилле, входящих в его структуру [9, 10, 25, 26], установлены железо, хром, скандий. Средние содержания их даны в табл. 2. Наиболее обогащены железом кристаллы берилла Саханаского месторождения и Шерловой Горы, а минимальны его содержания в берилле Спокойнинскго месторождения. При этом содержание его возрастает в ряду сидерофиллит-кварцевые (Спокойниниское) $\rightarrow$ слюдисто-берилл-топаз-кварцевые (Шерловая Гора) грейзены и камерные (Саханай) $\rightarrow$ редкометалльные (Орловское) пегматиты. Также в грейзенах ведут себя хром и скандий, что, как было показано в [10], обусловлено прямой связью между содержаниями железа и скандия в берилле на примере Шерловой Горы. Сравнительно высокое содержание хрома в берилле Шерловой Горы свидетельствует о присутствии среди них изумруда, хромофором которого наряду с хромом является ванадий [10].

Таблица 2. Средние содержания изоморфных элементов, замещающих в кристаллах берилла алюминий

Table 2. Average content of isomorphic elements, the residual crystals of beryl aluminium

\begin{tabular}{|c|c|c|c|}
\hline \multirow[t]{2}{*}{$\begin{array}{c}\text { Месторождение } \\
\text { Deposit }\end{array}$} & \multicolumn{3}{|c|}{$\begin{array}{c}\text { Элемент и его содержание, } \\
\text { ppm } \\
\text { Element and its content, ppm }\end{array}$} \\
\hline & $\mathrm{Fe}$ & $\mathrm{Cr}$ & $\mathrm{Sc}$ \\
\hline $\begin{array}{l}\text { Спокойнинское } \\
\text { Spokoyninskoe }\end{array}$ & 2840 & $<0,5$ & 0,86 \\
\hline $\begin{array}{l}\text { Шерловая Гора } \\
\text { Sherlovaya Gora }\end{array}$ & 5250 & 4,58 & 46,03 \\
\hline Орловское/Orlovskoe & 4530 & 1,57 & 17,05 \\
\hline Саханайское/Sakhanayskoe & 5260 & 1,17 & 2,33 \\
\hline
\end{tabular}

Содержания хрома варьируют от 0,5 ppm до 8,9. При этом почти все значащие числа содержаний принадлежат бледно-голубым кристаллам, в меньшей мере - бледно-зеленым, зеленая составляющая в которых визуально почти не отмечается. Но максимальное содержание хрома, в сравнении с другими изученными кристаллами, обнаружено в одном желтозеленом кристалле, где хром ассоциирует с железом, вероятно, в трехвалентной форме [10] и табл. 2.

Одной из особенностей изученных кристаллов берилла являются нетипичные для него примеси цинка, кобальта, золота, мышьяка и сурьмы (табл. 3)

Таблица 3. Содержание нетипичных примесей в берилле Table 3. Content of atypical impurities in beryl

\begin{tabular}{|l|c|c|c|c|c|}
\hline \multirow{2}{*}{\begin{tabular}{c}
\multirow{2}{*}{$\begin{array}{c}\text { Месторождение } \\
\text { Deposit }\end{array}$} \\
\cline { 2 - 6 }
\end{tabular}} & \multicolumn{5}{|c|}{ Элемент и его содержание, ppm } \\
\cline { 2 - 7 } & $\mathrm{Zn}$ & $\mathrm{Co}$ & $\mathrm{Au}$ & $\mathrm{As}$ & $\mathrm{Sb}$ \\
\hline $\begin{array}{l}\text { Cаханайское } \\
\text { Sakhanayskoe }\end{array}$ & 181,3 & 0,432 & $<0,005$ & 0,375 & 0,118 \\
\hline Орловское/Orlovskoe & 179,8 & 0,511 & 0,082 & 2,817 & 0,07 \\
\hline $\begin{array}{l}\text { Шерловая Гора } \\
\text { Sherlovaya Gora }\end{array}$ & 133,2 & 0,353 & 0,048 & 9,038 & 0,375 \\
\hline $\begin{array}{l}\text { Cпокойнинское } \\
\text { Spokoyninskoe }\end{array}$ & 105,4 & $<0,2$ & $<0,005$ & 21,586 & 0,036 \\
\hline
\end{tabular}

Максимальные содержания цинка и кобальта присущи бериллу пегматитов (Саханайское и Орловское месторождения), а минимальные - грейзенам Спокойнинского месторождения. Золото в сверхкларковых содержаниях установлено в берилле Орловского месторождения и Шерловой Горы. Относительно высокие содержания золота, мышьяка и сурьмы в берилле Шерловой Горы вполне закономерны, так как на руд- 
ные тела вольфрамит-висмутин-берилл-кварцевого состава здесь наложена поздняя оловополиметаллическая минерализация с арсенопиритом, связанная с формированием крупного месторождения сульфидно-касситерит-силикатной формации Сопка Большая [14, 17, 20, 21], больше известным как Шерловогорское. Общая тенденция к положительной связи содержаний золота и кобальта (рис. 5) может свидетельствовать об их едином глубинном магматическом источнике. Исключение составляют пробы ШГ-
18 имп и ШГ-24 имп, содержащие максимальное количество золота и низкое кобальта. Обе эти пробы происходят из жил Шерловой Горы, содержащих, наряду со сфалеритом и галенитом, висмутин, с которым ассоциирует золото, и не более 1-2 \% арсенопирита, содержащего кобальт. Примесь золота в берилле Орловского месторождения может быть обусловлена присутствием в пегматитах висмутина, нередко содержащего теллур, с которым имеет обыкновение связываться золото.

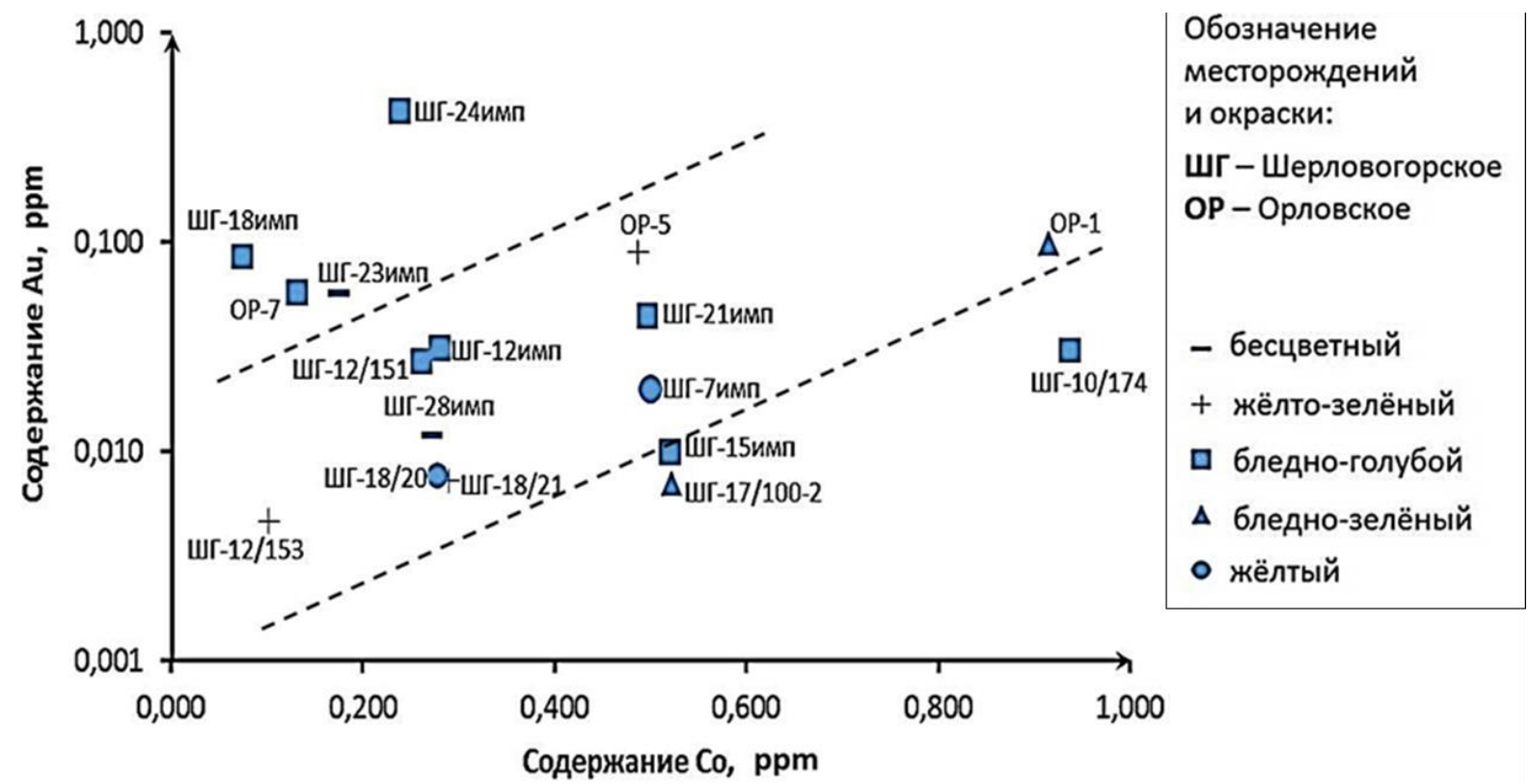

Pис. 5. Тренд тенденции к прямой связи содержаний золота и кобальта в берилле

Fig. 5. Trend of the tendency to direct relation of gold and cobalt contents in beryl

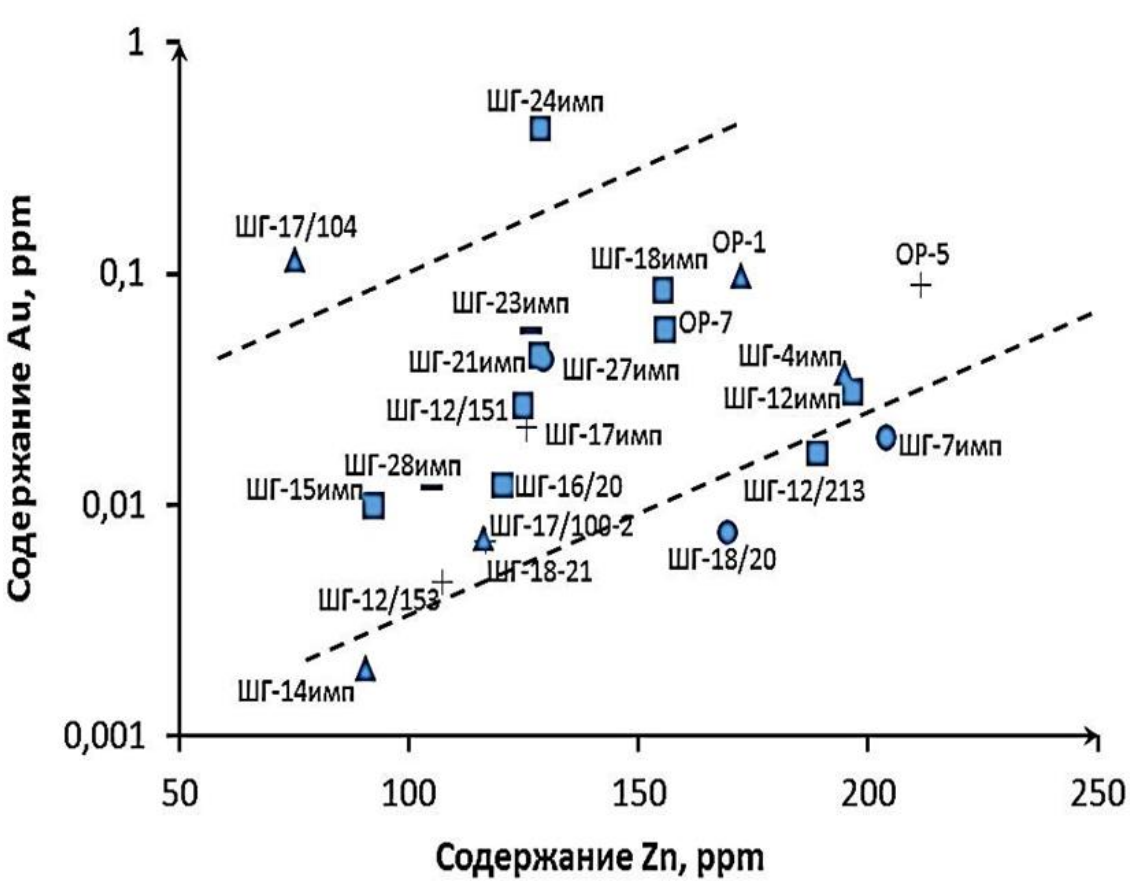

Обозначение месторождений и окраски:

ШГ-Шерловогорское ОР-Орловское

- бесцветный

+ жёлто-зелёный

口 бледно-голубой

$\Delta$ бледно-зелёный

○ жёлтый

Pис. 6. Тренд тенденции к прямой зависимости содержаний золота и иуикка

Fig. 6. Trend of the tendency to direct dependence of gold and zinc contents 
Как видно на рис. 6, содержание золота также имеет тенденцию к прямой связи с цинком, указывая на присутствие этих элементов в рудообразующих флюидах, формирующих всю рудную колонну, верхняя сэродированная касситеритовая часть которой содержала и халькофилы. Во всяком случае, большинство из определенных в берилле Шерловой Горы химических элементов присутствовали в минералообразующих флюидах [27].

Весьма интересен факт присутствия в берилле сверхкларковых содержаний мышьяка (табл. 3) Максимальные его содержания установлены в берилле кварцево-вольфрамитовых жил в сидерофиллиткварцевых грейзенах Спокойнинского месторождения. Это соответствует тому, что в продуктивных жилах этого месторождения присутствует сульфидная ассоциация. Более того, на современном уровне эрозии вскрыта относительно глубокая часть рудной колонны, характеризовавшейся четкой вертикальной зональностью. До 1939 г. Спокойнинское месторождение разрабатывалось как касситерит-силикатное, в рудах которого присутствовали сульфиды и с которым связаны отработанные в первой половине XX в. оловоносные россыпи. Зависимости между содержаниями цинка и мышьяка для всех образцов не выявлено. Ожидаемая прямая зависимость проявляется лишь для кристаллов, где содержания мышьяка существенно более 5 ppm, что характерно для кристаллов с Шерловой Горы и отдельных проб Спокойнинского и Орловского месторождений.

Уран и торий в рассматриваемых кристаллах берилла образуют различные концентрации (табл. 1): максимальные средние содержания урана (4,355 ppm) присущи бериллу Спокойнинского месторождения, минимальные $(0,651 \mathrm{ppm})$ - Орловского. В берилле грейзенов Шерловой Горы и камерном пегматите Са- ханайского средние содержания урана составляют $(\mathrm{ppm})$, соответственно, 1,899 и 1,597. В целом содержания урана в изученных кристаллах берилла в 1,5-2 раза выше его кларка для земной коры. В отличие от урана, содержания тория в изученных кристаллах берилла существенно ниже кларка и средние его значения находятся в пределах (ppm) от 0,138 для кварцмусковитовых грейзенов Спокойнинского месторождения до 3,187 кварц-топазовых грейзенов Шерловой Горы. Средние содержания тория в берилле пегматитов составляют: для Саханаййского 1,43 ppm и Орловского 0,283 ppm. Уран-ториевое отношение максимально для берилла Спокойнинского $(31,56)$ и минимально для берилла Шерловой Горы $(0,60)$. В берилле пегматитов Саханайского $(1,12)$ и Орловского $(2,3)$ месторождений уран преобладает над торием. Анализ этих данных свидетельствует о том, что существует четкая тенденция уменьшения содержания урана в слюдисто-берилл-топаз-кварцевых жильных телах (Шерловая Гора) по сравнению с сидерофиллит-берилл-вольфрамит-кварцевыми (Спокойнинское). Максимальные содержания тория установлены в кристаллах берилла слюдисто-берилл-топазкварцевых тел (Шерловая Гора). При этом проявлена тенденция уменьшения уран-ториевого отношения в рядах: сидерофиллит-кварцевые (Спокойнинское) $\rightarrow$ слюдисто-берилл-топаз-кварцевые (Шерловая Гора) грейзены и редкометалльные (Орловское) $\rightarrow$ камерные (Саханай) пегматиты.

Факт минимального содержания урана в берилле пегматитов по сравнению с таковыми грейзенов может свидетельствовать о длительности его нахождения в миграционном состоянии по сравнению с торием. В целом наблюдается тенденция к прямой зависимости между содержаниями $\mathrm{U}$ и Th в изученных кристаллах берилла (рис. 7).
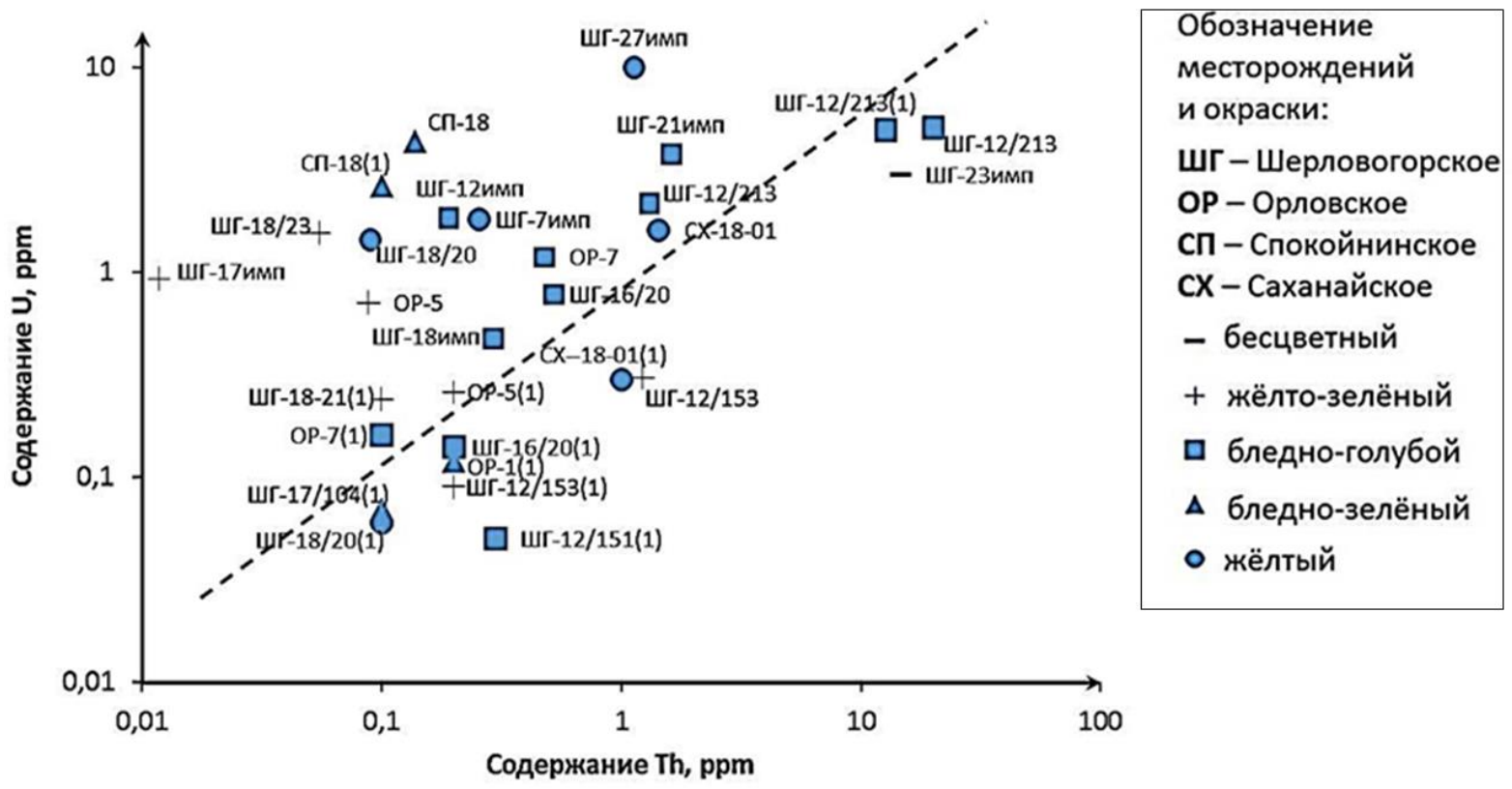

Pис. 7. Соотношения содержания урана и тория в кристаллах берилла

Fig. 7. Ratios of uranium and thorium content in beryl crystals 
Анализ этого рисунка показывает, что четче всего это проявлено в массиве бледно-голубых кристаллов Шерловой Горы. Для желто-зеленых и желтых она не проявлена, и намечается обратная связь. Это может быть обусловлено относительно высокой примесью окисного железа в гелиодорах, которое избирательно сорбирует более подвижный в гидротермальных условиях уран по сравнению с торием (рис. 7). Намечается обратная связь между ураном и торием в желто-зеленых кристаллах, что может быть связано с преимущественным накоплением урана вместе с железом. Вероятность связи содержаний урана с железом показана на рис. 8. Достаточно четко она выражена для желтых и желто-зеленых кристаллов, в которых наблюдаются зоны перерыва в росте, где накапливается окисленное железо и циркон, как показано в $[10,28]$. Исключение составляют образцы Ор1с высоким содержанием железа в кристалле, лишенном его неструктурной примеси, изоморфной, с которой не связан уран.

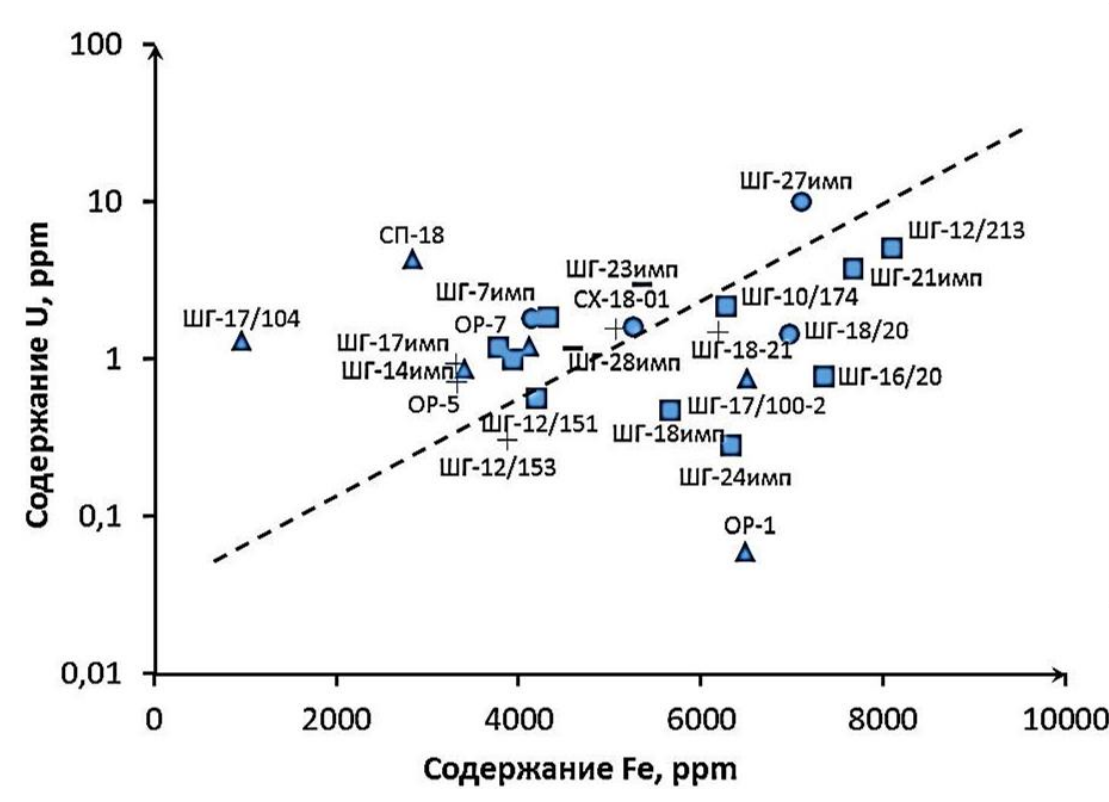

Обозначение месторождений и окраски:

шг-Шерловогорское ОР - Орловское СП - Спокойнинское CX - Саханайское

- бесцветный

+ жёлто-зелёный

口 бледно-голубой

$\Delta$ бледно-зелёный

○ жёлтый

Pис. 8. Соотношение содержаний урана и железа в берилле

Fig. 8. Ratio of uranium and iron in beryl

Для подхода к объяснению возможной связи содержаний тория с цирконом в берилле, что нами было описано в [28], на рис. 9 показана тенденция к зависимости содержаний тория и гафния - обычного ком- понента циркона. Как видно, существует тенденция к прямой связи его содержаний с торием. Исключение составляет бесцветный кристалл (ШГ-23 имп) с тонкой примесью флюидных включений.

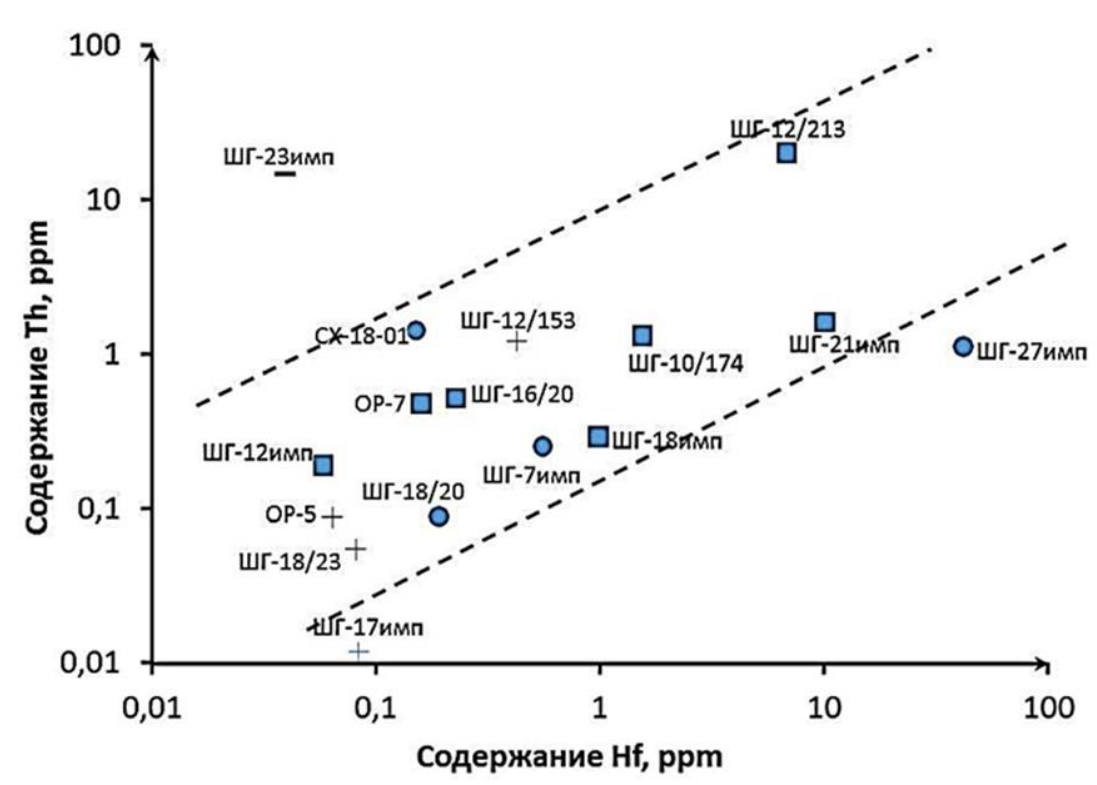

Рис. 9. Тенденция к прямой связи содержаний тория и гафния в кристаллах берилла

Fig. 9. Tendency to a direct relationship of thorium and hafnium contents in beryl crystals 
Имеющиеся данные о химическом составе флюидных включений в берилле Шерловой горы [27] показали, что все рассмотренные выше химические элементы присутствуют в них в концентрациях, достаточных для их определения. Установлено, что берилл Шерловой Горы формируется в результате эволюции остаточных расплавов с отделением высокотемпературных флюидов с высокой долей магматогенных компонентов в температурном интервале 633-247 ${ }^{\circ} \mathrm{C}$. Эти флюиды содержали (\%) мышьяк $(0,95-6,3)$, рубидий $(0,01-1,2)$, цезий $(0,01-1,7)$, литий $(0,2-3,0)$, сурьму, цинк, кадмий, свинец, торий, уран, железо, кобальт, никель, хром, ванадий, иттрий, цирконий, гафний, редкие земли и другие элементы [27].

Из табл. 1 видно, что нейтронно-активационным методом определены содержания лишь восьми редкоземельных элементов. На рис. 10 показано распределение их содержаний по кристаллам различной окраски. Для определения РЗЭ методом ISP MS было недостаточно материала для всего массива проб.

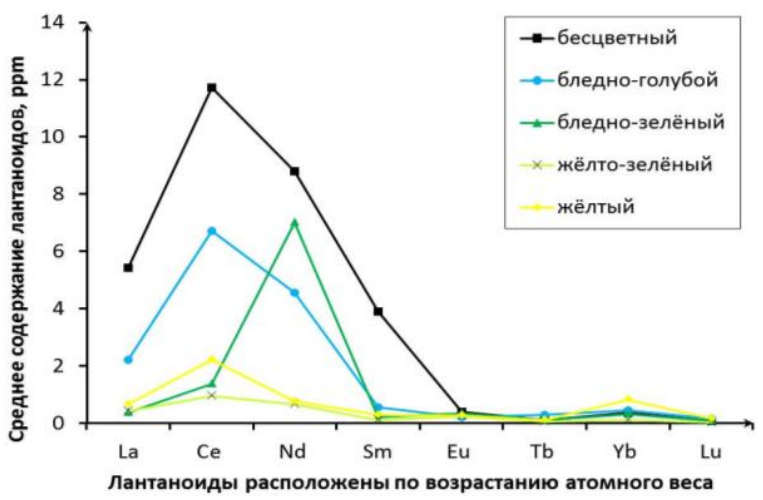

Pис. 10. РЗЭ в кристаллах берилла разной окраски

Fig. 10. REE in beryl crystals of different colors

Однозначно проявлена тенденция к относительно высокому накоплению легких РЗЭ относительно тяжелых. При этом для всех цветовых разностей, кроме бледно-зеленых, типичен цериевый максимум. Средние содержания тяжелых РЗЭ не превышают 1 ppm. Наибольшие содержания присущи иттербию. Бледнозеленые отличаются максимальным содержанием неодима, хотя высокие его содержания типичны также для бесцветных и бледно-голубых разностей.

В целом содержания легких РЗЭ возрастают в ряду: желтые $\rightarrow$ желто-зеленые $\rightarrow$ бледно-зеленые $\rightarrow$ бледноголубые $\rightarrow$ бесцветные. Эта особенность может быть связана с тем, что последовательность образования цветовых разновидностей берилла, от бесцветных в начале процесса до желтых (гелиодор) в конце, отображает уменьшение содержаний РЗЭ в минералообразующей системе в этом направлении. Это и может определять вероятность захвата их кристаллами берилла [7].

\section{Выводы}

1. Установлен широкий диапазон концентраций элементов-примесей в кристаллах берилла различного цвета сидерофиллит-кварцевых (Спокойнинское месторождение вольфрама) и слюдисто- берилл-топаз-кварцевых (Шерловая Гора) грейзенов, а также редкометалльных (Орловское) и камерных (Саханайское) пегматитов.

2. Кристаллы берилла слюдисто-берилл-топазкварцевых (Шерловая Гора) грейзенов отличаются низкими содержаниями натрия и цезия по сравнению с таковыми из сидерофиллит-кварцевых грейзенов и пегматитов. Рубидий примерно в равной мере присутствует в кристаллах берилла всех изученных месторождений независимо от окраски.

3. Впервые в кристаллах берилла обнаружено золото, содержания которого имеют тенденцию к связи с кобальтом и цинком, что вполне правомерно. Мышьяк, изоморфное вхождение которого в берилл маловероятно, также имеет тенденцию к связи с цинком и кобальтом. Все халькофилы и элементы V группы Периодической системы (мышьяк, сурьма, висмут) присутствуют во флюидных включениях в берилле Шерловой Горы [27], и присутствие их в нем обусловлено геохимическими особенностями минералообразующих систем этого месторождения.

4. Примесь железа, установленная в большинстве изученных кристаллов, наиболее высокие содержания имеет в желтых, голубых и желто-зеленых кристаллах, входя в тетраэдрические (голубые) и октаэдрические позиции (желтые и желтозеленые), что было показано ранее [7, 10].

5. Примеси урана и тория, присутствующие во всех изученных кристаллах берилла, тем не менее, имеют тенденцию к наибольшему накоплению в кристаллах берилла грейзенов (Шерловая Гора, Спокойнинское) по сравнению с пегматитами. Содержания их имеют тенденцию к взаимозависимости при преобладании тория над ураном. Установлено, что накопление урана имеет тенденцию к связи с железом, наибольшие концентрации которого присущи зональным кристаллам с перерывами в росте. Торий связан в основном с цирконом, присутствие которого установлено в [28], что подтверждается тенденцией к положительной связи содержаний тория и гафния.

6. Из установленных и берилле редких земель максимальными содержаниями характеризуются легкие ( $\mathrm{La}, \mathrm{Ce}, \mathrm{Nd})$ элементы. Содержания их возрас-

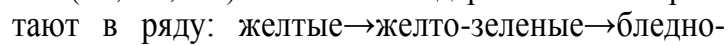
зеленые $\rightarrow$ бледно-голубые $\rightarrow$ бесцветные.

7. Результаты исследования относительно широкого спектра примесей в кристаллах берилла показали обусловленность их различиями в условиях образования (грейзены и пегматиты) и геохимическими особенностями минералообразующих флюидных систем, отображенных в составе флюидных включений [27-30].

Авторы выражают благодарность Роману Андреевичу Филенко за помощь в подготовке к анализам образиов Спокойнинского и Орловского месторождений и составлению puc. 1 .

Работа выполнена в соответствии с госзаданием по проекту № 0386-2015-0006 (IX.137.1.2.). 


\section{СПИСОК ЛИТЕРАТУРЫ}

1. Минералы: справочник / гл. ред. акад. Ф.В. Чухров, отв. ред. к.г.-м.н. Н.Н. Смольянинова. - М.: Наука, 1981. - Т. III. Вып. 2. -614 с.

2. Буканов В.В. Цветные камни. Геммологический словарь. СПб.: АОЗТ «Изд-во Медный всадник», 2001. - 208 с.

3. Киевленко Е.Я. Геология самоцветов. - М.: Ассоциация ЭКОСТ, 2000. - $582 \mathrm{c}$.

4. Куприянова И.И., Шпанов Е.П. Бериллиевые месторождения России. - М.: ГЕОС, 2011. - 354 c.

5. Bank, H. Das Smaragd-Alexandritvorkommen von Lake Manyara (Tansania) // Z. dtsch. gemmol. Ges. - 1976. - B. 25. - № 3. P. 130-147.

6. Платонов А.Н., Таран М.Н., Балицкий В.С. Природа окраски самоцветов. - М.: Недра, 1984. - 196 с.

7. Typomorphic peculiarities of noble beryl varieties from Sherlovaya Montain / G.A. Yurgenson, A.S. Afanasieva, O.V. Kononov, V.Yu. Prokofiev // Geology and Resources. 2010. - V. 19. - № 1 Aug. - P. 28-30.

8. Taran M.N., Vyshnevskyi O.A. Be, Fe2+-substitution in natura beryl: an optical absorption spectroscopy study // Physics and Chemistry of Minerals. - June 2019. - P. 7-17. DOI: 10.1007/s00269-019-01040

9. Spinolo G., Fontana I., Galli A. Optical absorption spectra of $\mathrm{Fe}^{2+}$ and $\mathrm{Fe}^{3+}$ in beryl crystals // Physica status solidi. - 2007. - V. 244. № 12. - P. 4660-4668. DOI: 10.1002/pssb.200743102

10. Борзенко А.А., Юргенсон Г.А. Скандий, иттрий и лантаноиды в берилле Шерловой Горы // Минералы: строение, свойства, методы исследования. - 2019. - № 10. - С. 33-35.

11. Лопатин О.Н., Николаев А.Г., Хайбуллин Р.И. Кристаллохимические аспекты имплантации минералов и их синтетических аналогов // Записки Российского минералогического общества. - 2012. - Ч. СXLI. - № 1. - С. 61-69.

12. Николаев А.Г., Фахардо Бехарано Э.Л., Попов М.П. Оптическая спектроскопия и сравнительные кристаллохимические особенности изумрудов различных промышленногенетических типов месторождений // Металлогения современных и древних океанов-2016. От минералогенеза к месторождениям. - Миасс: ИМин УрО РАН, 2016. - С. 236-239.

13. Coloration of natural beryl by iron ion implantation / R.I. Khaibullin, V.V. Bazarov, I.B. Khaibullin, O.N. Lopatin, F.G. Vagizov, A.I. Bakhtin, B. Aktas // Nuclear Instruments and Methods in Physics Research Section B: Beam Interactions with Materials and Atoms. - 2003. - T. 206. - C. 277-281.

14. Гайворонский Б.А. Шерловогорское месторождение // Месторождения Забайкалья. Т. І. Кн. 1 / под ред. акад. Н.П. Лаверова. - М.: Геоинформмарк, 1995. - С. 130-133.

15. Онтоев Д.О. Стадийность минерализации и зональность месторождений Забайкалья. - М.: Наука, 1974. - 244 с.

16. Барабанов В.Ф., Ступкина Л.О. О твердых включениях в топазах Шерловой Горы // Вестник Ленингр. гос. ун.-та. - 1955. № 10. - С. 97-109.
17. Tzschorn G. Zur Mineralogie der Topasgange der Schrlberge (Osttransbaikalien). - Geologie. - 1963 Jahrgang 12. - H. 3. - S. 283311.

18. Барабанов В.Ф. Минералогия вольфрамитовых месторождений Забайкалья. Т. 2 - Л.: Изд-во Ленингр. ун-та, 1975. - 360 с

19. Геологическое строение Читинской области. Объяснительная записка к геологической карте масштаба 1:500000 / К.К. Анашкина, К.С. Бутин, Ф.И. Еникеев, А.В. Кинякин, В.П. Краснов, В.А. Кривенко, Б.И. Олексив, Т.А. Пинаева, И.Г. Рутштейн, В.Н. Семенов, Л.П. Старухина, Н.Н. Чабан, Е.В. Шулика. - Чита: Читагеолком, 1997. - 239 с

20. Юргенсон Г.А. Ювелирные камни Забайкалья. - Чита: Изд-во Забайкальск. гос. ун-та, 2016. - Ч. 1. - 147 с.

21. Yurgenson G.A., Kononov O.V. Sherlova Gora: a deposit for gemstones and rare metals // Mineralogical Almanac. - 2014. V. 19. - Iss. 2. - P. 12-93.

22. Авдеевит - Na-доминантный щелочной берилл: установление статуса минерального вида и новые данные / А.А. Агаханов, Д.А. Степаненко, Н.В. Зубкова, Л.А. Паутов, И.В. Пеков, А.В. Касаткин, В.Ю. Карпенко, В.А. Агаханова, Р. Шкода, С.Н. Бритвин, Д.Ю. Пущаровский // Записки российского минералогического общества. - 2020. - Ч. CXLIX. - № 6. - C. 1-19.

23. Oftedal I. Lithium contents of Norvegian beryls // Norsk geologisk tidskrift. - 1970. - V. 50. - № 3. - P. 245-247.

24. Wood D.L., Nassau K. The characterization of beryl and emerald by visible and infrared absorbtion spectroscopy // American Mineralogist. - 1968. - V. 53. - P. 777-800.

25. Бакакин В.В., Рылов Г.М., Белов Н.В. Рентгенографическая диагностика изоморфных разновидностей берилла // Геохимия. - 1970. - № 11. - С. 1302-1311.

26. Demartin F., Gramaccioli C.M., Pilati T. Structure refinement of bazzite from pegmatitic and miarolitic occurrences // The Canadian Mineralogist. - 2000. - № 38. - P. 1419-1424.

27. Fluid inclusion in beryl of Sherlovay Gora deposit (Eastern Transbaikalia, Russian Federation) / G. Yurgenson, V. Prokofiev, A. Afanasieva, O. Kononov //Acta minerelogica-petrographica. Abstract series. - 2019. -V. 10. - P. 126.

28. Юргенсон Г.А., Борзенко А.А. Циркон в зональных кристаллах берилла Шерловой Горы (Юго-Восточное Забайкалье) Успехи современного естествознания. - 2018. - № 11. C. 173-178. DOI: 10.175/use.36923

29. Высокотемпературный берилл из Супруновского месторождения бесполостных гранитных пегматитов (Иркутская область, Россия) / Е.И. Герасимова, В.Ю. Прокофьев, С.3. Смирнов, Т.Н. Ковальская // Геохимия. - 2019. - Т. 64. - № 7. C. $750-756$. DOI: $10.31857 / \mathrm{S} 0016-7525647750-756$

30. Возраст и изотопная характеристика Булуктаевского молибден-вольфрамового месторождения (Республика Бурятия) / А.А. Савченко, Г.С. Рипп, И.А. Избродин, В.Ф. Посохов // Известия Сибирского отделения секции наук о Земле Российской академии естественных наук. Геология, разведка и разработка месторождений полезных ископаемых. - 2018. T. 41. - № 4 (65). - C. 7-21.

Поступила 10.09.2020 2.

\section{Информация об авторах}

Юргенсон Г.А., доктор геолого-минералогических наук, главный научный сотрудник лаборатории геохимии и рудогенеза Института природных ресурсов, экологии и криологии Сибирского отделения Российской академии науки.

Рихванов Л.П., доктор геолого-минералогических наук, профессор отделения геологии Института природных ресурсов Томского политехнического университета.

Борзенко $\boldsymbol{A}$.А., инженер лаборатории геохимии и рудогенеза Института природных ресурсов, экологии и криологии Сибирского отделения Российской академии науки. 
UDK 549.6

\title{
FEATURES OF COMPOSITION OF IMPURITIES IN BERYL CRYSTALS OF VARIOUS COLORS OF TRANSBAIKALIA
}

\author{
Georgy A. Yurgenson ${ }^{1}$, \\ yurgga@mail.ru
}

\section{Leonid P. Rikhvanov ${ }^{2}$}

\author{
Alena A. Borzenko', \\ avonanik@mail.ru \\ 1 Institute of Natural Resources, Ecology and Cryology, Siberian Branch of the Russian Academy of Sciences, \\ 16a, Nedoreosv street, Chita, 672014, Russia. \\ 2 National Research Tomsk Polytechnic University, \\ 30, Lenin avenue, Tomsk, 634050, Russia.
}

The relevance of the work lies in the study of the features of the chemical composition of beryl, which is an important source of beryllium and gemstone, the gemological properties of which are determined by the concentrations and forms of occurrence of impurity chemical elements.

The aim of the study is to determine the content of impurity chemical elements in beryl crystals of various colors, the relationships between them and the relationship with the conditions of formation.

Objects of the research are crystals of beryl of different colors of greisen (Sherlovaya Gora, Spokoyninskoe) and pegmatite (Orlovskoe, Sachanayskoe) fields.

Methods of the research are neutron activation and ICP MS.

Results. The authors have established a wide range of concentrations of impurity elements in 31 beryl crystals of various colors, siderophyllite-quartz (Spokoininskoe deposit of tungsten) and mica-beryl-topaz-quartz (Sherlovaya Gora) greisens, as well as rare-metal (Orlovskoe) and chamber pegmatites (Sakhanayskoe). Beryl crystals of mica-beryl-topaz-quartz (Sherlovaya Gora) greisens are characterized by low sodium and cesium contents in comparison with those of siderophyllite-quartz greisens and pegmatites. Rubidium is approximately equally present in beryl crystals of all the studied deposits, regardless of color. For the first time, gold was found in them, the contents of which tend to be associated with cobalt and zinc. The content of arsenic, the isomorphic incorporation of which into beryl is unlikely, also shows a correlation to the bond with zinc and cobalt. The highest iron contents are found in yellow, blue and yellow-green crystals, entering both tetrahedral (blue) and octahedral positions (green, yellow, and yellow-green). The content of uranium and thorium is higher in the crystals of beryl greisens (Sherlovaya Gora, Spokoininskoe) in comparison with pegmatites. Their contents tend to be interdependent when thorium predominates over uranium. Uranium has bonds with iron, the highest concentrations of which are inherent in zonal crystals with breaks in growth. Thorium is associated mainly with zircon, which is confirmed by the positive correlation of its contents with hafnium. A relatively wide range of impurities in beryl crystals is due to differences in the conditions of formation (greisens and pegmatites) and the geochemical features of the mineral-forming fluid systems reflected in the composition of fluid inclusions.

\section{Key words:}

Beryl, trace elements, relationships between trace elements, greisens, pegmatites,

Sherlovaaya Gora, Orlovskoe deposit, Spokoininskoe deposit, Sakhanayskoe deposit.

The authors appreciate Roman A. Filenko for assistance in preparing samples of Spokoininskoe and Orlovskoe fields for analysis and preparing Fig. 1.

The research was carried out according to the state task by the project no. 0386-2015-0006 (IX.137.1.2.).

\section{REFERENCES}

1. Mineraly: spravochnik [Minerals: Reference]. Eds. F.V. Chukhrov, N.N. Smolyaninova. Moscow, Nauka Publ., 1981. Vol. III, Iss. 2, $614 \mathrm{p}$.

2. Bukanov V.V. Tsvetnye kamni. Gemmologicheskiy slovar [Colored stones. Gemological Dictionary]. St. Petersburg, AOZT Bronze Horseman Publ. House, 2001. 208 p.

3. Kiyevlenko E.YA. Geologiya samotsvetov [Geology of gems]. Moscow, ECOST Association Publ., 2000. 582 p.

4. Kupriyanova I.I., Shpanov E.P. Berillievye mestorozhdeniya Rossii [Beryllium deposits of Russia]. Moscow, GEOS Publ., 2011. 354 p.

5. Bank H. The emerald-alexandrite deposit of Lake Manyara (Tasmania). Z. dtsch. gemmol. Ges., 1976, vol. 25, no. 3, pp. 130-147. In Germ.

6. Platonov A.N., Taran M.N., Balitskiy V.S. Priroda okraski samotsvetov [The nature of the color of gems]. Moscow, Nedra Publ., 1984. $196 \mathrm{p}$.
7. Yurgenson G.A., Afanasieva A.S., Kononov O.V., Prokofiev V.Yu. Typomorphic peculiarities of noble beryl varieties from Sherlovaya Montain. Geology and Resources, 2010, vol. 19, no. 1, pp. 28-30.

8. Taran M.N., Vyshnevskyi O.A. Be, Fe $e^{2+}$-substitution in natural beryl: an optical absorption spectroscopy study. Physics and Chemistry of Minerals, 2019, pp. 7-17. DOI: 10.1007/s00269-01901040

9. Spinolo G., Fontana I., Galli A. Optical absorption spectra of $\mathrm{Fe}^{2+}$ and $\mathrm{Fe}^{3+}$ in beryl crystals. Physica status solidi, 2007, vol. 244, no. 12, pp. 4660-4668. DOI 10.1002/pssb.200743102

10. Borzenko A.A., Yurgenson G.A. Scandium, yttrium and lanthanides in the beryl of Sherlova Gora. Minerals: structure, properties, research methods, 2019, no. 10, pp. 33-35. In Rus.

11. Lopatin O.N., Nikolaev A.G., Khaybullin R.I. Crystal-chemical aspects of implantation of minerals and their synthetic analogues. Zapiski Rossiyskogo mineralogicheskogo obshchestva, 2012, P. CXLI, no. 1, pp. 61-69. In Rus. 
12. Nikolaev A.G., Fakhardo Bekharano E.L., Popov M.P. Opticheskaya spektroskopiya i sravnitelnye kristallokhimicheskie osobennosti izumrudov razlichnykh promyshlenno-geneticheskikh tipov mestorozhdeniy [Optical spectroscopy and comparative crystal-chemical features of emeralds of various industrial and genetic types of deposits]. Metallogeniya sovremennykh $i$ drevnikh okeanov-2016. Ot mineralogeneza $k$ mestorozhdeniyam [Metallogeny of modern and ancient oceans-2016. From mineralogenesis to deposits]. Miass, IMin UrO RAN Publ., 2016. pp. 236-239.

13. Khaibullin R.I., Bazarov V.V., Khaibullin I.B., Lopatin O.N., Vagizov F.G., Bakhtin A.I., Aktas B. Coloration of natural beryl by iron ion implantation. Nuclear Instruments and Methods in Physics Research Section B: Beam Interactions with Materials and Atoms, 2003, vol. 206, pp. 277-281.

14. Gayvoronskiy B.A. Sherlovogorskoe mestorozhdenie [Sherlovogorskoe deposit]. Mestorozhdeniya Zabaykalya [Deposits of Transbaikalia]. Ed. by N.P. Laverov. Moscow, Geoinformmark Publ., 1995. Vol. I. B. 1. pp. 130-133.

15. Ontoev D.O. Stadiynost mineralizatsii i zonalnost mestorozhdeniy Zabaykalya [Staged of mineralization and zoning of Transbaikalia deposits]. Moscow, Nauka Publ., 1974. 244 p.

16. Barabanov V.F., Stupkina L.O. O tverdykh vklyucheniyakh v topazakh Sherlovoy Gory [On solid inclusions in the topazes of Sherlova Gora]. Bulletin of the Leningrad State University, 1955, no. 10 , pp. $97-109$.

17. Tzschorn G. To mineralogy of topaz occurrences of Sherlova Gora (Eastern Transbaikalia). Geologie, 1963, vol. 12, N. 3, pp. 283-311 In Germ.

18. Barabanov V.F. Mineralogiya volframitovykh mestorozhdeniy Zabaykalya [Mineralogy of tungsten deposits of Transbaikalia]. Leningrad, Leningrad University Publ. house, 1975. Vol. 2. 360 p.

19. Anashkina K.K., Butin K.S., Enikeev F.I., Kinyakin A.V., Krasnov V.P., Krivenko V.A., Oleksiv B.I., Pinayeva T.A., Rutshteyn I.G., Semenov V.N., Starukhina L.P., Chaban N.N., Shulika E.V. Geologicheskoe stroenie Chitinskoy oblasti. Obyasnitelnaya zapiska $k$ geologicheskoy karte masshtaba 1:500000 [Geological structure of the Chita region. Explanatory note to the geological map of 1:500000 scale]. Chita, Chitageolkom Publ., 1997. $239 \mathrm{p}$.

20. Yurgenson G.A. Yuvelirnye kamni Zabaykalya [Jewelry stones of Transbaikalia]. Chita, Zabaikalsk University Publ. house, 2016. P. 1,147 p.
21. Yurgenson G.A., Kononov O.V. Sherlova Gora: a deposit for gemstones and rare metals. Mineralogical Almanac, 2014, vol. 19, Iss. 2, pp. 12-93.

22. Agakhanov A.A., Stepanenko D.A., Zubkova N.V., Pautov L.A., Pekov I.V., Kasatkin A.V., Karpenko V.Yu., Agakhanova V.A., Shkoda R., Britvin S.N., Pushcharovskiy D.Yu. Avdeevite - Nadominant alkaline beryl: establishing the status of a mineral species and new data. Zapiski rossiyskogo mineralogicheskogo obshchestva, 2020, P. CXLIX, no. 6, pp. 1-19. In Rus.

23. Oftedal I. Lithium contents of Norvegian beryls. Norsk geologisk tidskrift, 1970, vol. 50, no. 3, pp. 245-247.

24. Wood D.L., Nassau K. The characterization of beryl and emerald by visible and infrared absorbtion spectroscopy. American Mineralogist, 1968, vol. 53, pp. 777-800

25. Bakakin V.V., Rylov G.M., Belov N.V. Rentgenograficheskaya diagnostika izomorfnykh raznovidnostey berilla [Radiographic diagnosis of isomorphic varieties of beryl]. Geochemistry, 1970, no. 11, pp. 1302-1311.

26. Demartin F., Gramaccioli C.M., Pilati T. Structure refinement of bazzite pegmatitic and miarolitic occurrences. The Canadian Mineralogist, 2000, no. 38, pp. 1419-1424.

27. Yurgenson G., Prokofiev V., Afanasieva A., Kononov O. Fluid inclusion in beryl of Sherlovay Gora deposit (Eastern Transbaikalia, Russian Federation). Acta minerelogica-petrographica. Abstract series, 2019, vol. 10, pp. 126

28. Yurgenson G.A., Borzenko A.A. Zircon in zonal crystals of beryl of Sherlova Gora (Southeast Transbaikalia). Advances in modern science, 2018, no. 11, pp. 173-178. In Rus. DOI: 10.175/use.36923.

29. Gerasimova E.I., Prokofyev V.Yu., Smirnov S.Z., Kovalskaya T.N High-temperature beryl from the Suprunovskoe deposit of empty granite pegmatites (Irkutsk region, Russia. Geochemistry, 2019, vol. 64, no. 7, pp. 750-756. DOI: 10.31857/S0016-7525647750-756. In Rus.

30. Savchenko A.A., Ripp G.S., Izbrodin I.A., Posokhov V.F Age and isotopic characteristics of Buluktaevsky molybdenum-tungsten deposit (Republic of Buryatia). Bulletin of the Siberian Branch of the Earth Sciences Section of the Russian Academy of Natural Sciences. Geology, exploration and development of mineral deposits, 2018, vol. 41, no. 4 (65), pp. 7-21. In Rus.

Received: 10 September 2020.

\section{Information about the authors}

Georgy A. Yurgenson, Dr. Sc., professor, Institute of natural resources, ecology and Cryology of the Siberian branch of the Russian Academy of science.

Leonid P. Rikhvanov, Dr. Sc., professor, National Research Tomsk Polytechnic University.

Alena A. Borzenko, engineer, Institute of natural resources, ecology and Cryology of the Siberian branch of the Russian Academy of science. 